\title{
Root exudate profiling of maize seedlings inoculated with Herbaspirillum seropedicae and humic acids
}

Lívia da Silva Lima, Fábio Lopes Olivares', Rodrigo Rodrigues de Oliveira², Maria Raquel Garcia Vega², Natália Oliveira Aguiar ${ }^{1}$ and Luciano Pasqualoto Canellas ${ }^{1 *}$

\begin{abstract}
Background: Co-inoculation of maize with Herbaspirillum seropedicae and humic substances increases the sizes of plant-associated bacterial populations and enhances grain yields under laboratory and field conditions. Root exudation is a key mechanism in the regulation of plant-bacterial interactions in the rhizosphere; humic matter supplementation is known to change the exudation of $\mathrm{H}^{+}$ions and organic acids from maize roots. Our starting premise was that H. seropedicae and humic acids would modify maize seedling exudation profiles. We postulated that a better understanding of these shifts in exudate profiles might be useful in improving the chemical environment to promote better performance of plant growth-promoting bacteria delivered as bioinoculants. Thus, root exudates of maize were collected and analyzed by gas chromatography-mass spectrometry (GC-MS) and proton nuclear magnetic resonance ('H NMR).
\end{abstract}

Results: Nitrogenous compounds, fatty acids, organic acids, steroids, and terpenoid derivatives were the main structural moieties found in root exudates. Significant changes in exudation patterns occurred 14 days after the initiation of experiments. Quantities of fatty acids, phenols, and organic acids exuded by seedlings treated with humic acids alone differed from the quantities exuded in other treatments. Seedlings treated with $\mathrm{H}$. seropedicae or H. seropedicae in combination with humic acids exuded a diversity of nitrogenous compounds, most of which had heterocyclic structures. Twenty-one days after initiating the experiment, seedlings treated with $\mathrm{H}$. seropedicae alone exuded elevated quantities of steroids and terpenoid derivatives related to precursors of gibberellic acids (kaurenoic acids).

Conclusions: Changes in root exudation profiles induced by our treatments became most marked 14 and 21 days after initiation of the experiment; on those days, we observed (i) increased fatty acid exudation from seedlings treated only with humic acids and (ii) increased exudations of nitrogenated compounds and terpenes from seedlings treated only with $\mathrm{H}$. seropedicae. Improved knowledge on the effects of bacterial inoculants and supplementation with humates on plant exudate composition may contribute substantially to improved understanding of plant metabolic responses and lead to new approaches in the use of selected compounds as additives in bioinoculant formulations that will modulate the cross-talk between bacteria and plants, thereby improving crop yields.

Keywords: Plant growth-promoting bacteria; Endophytic interaction; Humic substances

\footnotetext{
* Correspondence: lucianocanellas@gmail.com

${ }^{1}$ Núcleo de Desenvolvimento de Insumos Biológicos para a Agricultura

(NUDIBA), Universidade Estadual do Norte Fluminense Darcy Ribeiro (UENF),

Av. Alberto Lamego, 2000, Campos dos Goytacazes, 28013-602 Rio de

Janeiro, Brazil

Full list of author information is available at the end of the article
} 


\section{Background}

Root exudates function in processes of plant adaptation. They have roles in nutrient cycling in the rhizosphere and in responses to pathogens and symbiotic microorganisms [1]. The quantities of organic compounds exuded by roots are variable, but they are frequently a significant proportion of the carbon fixed photosynthetically by plants [2]. Plant type, species, age, and environmental factors, including biotic and abiotic stressors, all affect exudation profiles $[3,4]$. The plant rhizosphere modulates microbial community structure and function, primarily through the release of chemical compounds [5].

The dominant organic compounds exuded by roots reflect central components of cell metabolism, including free sugars (e.g., glucose, sucrose), amino acids (e.g., glycine, glutamate), and organic acids (e.g., citrate, malate, and oxalate) [2]. Maize exudates comprise sugars (70\%), phenolics (18\%), organic acids (7\%), and amino acids (3\%) [6]. Other compounds, like fatty acids, sterols, enzymes, vitamins, and plant growth regulators (e.g., auxins, gibberellins, and cytokinins), are generally released in only very small quantities [7]. Although only small quantities of secondary metabolites are exuded by roots, their plant role in signaling to the microbial community is substantial [8].

Recently, we determined that the combined inoculation of maize with the endophytic diazotrophic bacterium Herbaspirillum seropedicae and humic acids increased root colonization and promoted plant growth and grain yields [9]. Canellas and Olivares [10] reviewed the use of humic substances as plant growth promoters; they considered the effects of these substances on plant metabolism and their use as carriers in procedures for the bioinoculation of plant growth-promoting bacteria in field crop systems.

Canellas et al. [11] reported changes in maize exudation profiles after humic acid application that included enhanced secretion of inorganic ions (i.e., $\mathrm{H}^{+}$ions) and short-chain organic acids [12]. The addition of humic acids of different size fractions may have substantial effects on the quantities of bioavailable carbon deposited by maize plant roots; these additions produce significant changes in the structure and activity of soil microbial communities [13]. Hence, chemical changes induced by humic matter augmentation in the rhizosphere may enhance colonization of maize plants by inoculated endophytic diazotrophic bacteria carried in the humic substances.

$H$. seropedicae is a plant growth-promoting diazotrophic $\beta$-proteobacterium found mainly in association with grasses and other non-leguminous plants [14]. Roesch et al. [15] used molecular tools to assess diazotrophic bacterial diversity within rhizosphere soils, roots, and stems of field-grown maize and observed a predominance of $\alpha$-proteobacteria and $\beta$-proteobacteria sequences in the rhizosphere soil and stem samples; Herbaspirillum was one of the dominant genera in the interiors of maize plants but was rarer in soil. The members of this genus have been tested in the formulation of biofertilizers, with variable success in field crop trials ([16-19] and references therein [20-23]). The whole genome sequence of $H$. seropedicae has been published [24]. The species' capacity for $\mathrm{N}$ fixation, production of auxin and other phytohormones, and the colonization of diverse plant species has been previously demonstrated [25-27].

Root colonization is a basic first step for successful inoculation. An expansion of studies on metabolite exchange between plants and bacteria and the genetic responses of plants will fill knowledge gaps in our understanding of the colonization process. The role of root-exuded flavonoids in legume-Rhizobium interactions has been examined in detail. These exudations generate a finely tuned cross-molecular dialogue involving the secretion of lipochitooligosaccharides and the modulation of bacterial cell wall surface polysaccharides (extracellular polysaccharide (EPS) and lipopolysaccharide (LPS)) that result in plant root nodulation [28]. There is less information available on the role of plant metabolites in successful interactions with non-nodulating plant growth-promoting bacteria. Gough et al. [29] showed that flavonoids promote endophytic colonization of Arabidopsis thaliana (L.) Heynh. roots by $H$. seropedicae, and Tadra-Sfeir et al. [30] demonstrated that naringenin (a flavonoid in the flavonone class) is involved in the gene expression of cell wall components (EPS, LPS) and auxins. In addition to its role in the genetic modulation of cell wall assembly, $H$. seropedicae has an operon associated with the degradation of aromatic compounds [31]. An ability to degrade flavonoids would likely confer an important competitive advantage in rhizosphere/root colonization of the host plant by providing both a carbon source and associated detoxification mechanisms. Balsanelli et al. [32] showed that surface lipopolysaccharides produced by H. seropedicae strain Smr1 are required for attachment and endophytic colonization of maize plants. They [32] found that the $H$. seropedicae attachment process is partially mediated by a root lectin that specifically binds $\mathrm{N}$-acetyl glucosamine residues.

Recently, Marks et al. [33] demonstrated the potential of using bacterial metabolites to enhance the performance of biofertilizers, thereby opening the possibility of chemical manipulation of carriers to benefit bacterial delivery to field crops. Furthermore, metabolites exuded by host plants may help in guiding genomic studies of plant-bacterial interactions. In the present work, we examined main changes in exudation profiles of maize seedling roots induced under laboratory conditions by (i) single applications of humic acids or (ii) $H$. seropedicae or (iii) combinations of the bacteria and humic acids. 


\section{Methods}

\section{Humic substances}

Humic-like substances were extracted as described previously [11]. In brief, ten volumes of $0.5 \mathrm{~mol} \mathrm{~L}^{-1} \mathrm{M}$ $\mathrm{NaOH}$ were mixed with one volume of earthworm compost under a $\mathrm{N}_{2}$ atmosphere. After $12 \mathrm{~h}$, the suspension was centrifuged at 5,000 $\times g$; humic acids (HA) were extracted thrice in this manner, and the final HA pellet was de-ashed by combining it with ten volumes of a diluted mixture of $\mathrm{HF}-\mathrm{HCl}$ solution $\left(5 \mathrm{~mL} \mathrm{~L}^{-1} \mathrm{HCl}[12 \mathrm{M}]+\right.$ $\left.5 \mathrm{~mL} \mathrm{~L}^{-1} \mathrm{HF}[48 \%, v / v]\right)$. After centrifugation $(5,000 \times g)$ for $15 \mathrm{~min}$, the sample was repeatedly washed with water until a negative test against $\mathrm{AgNO}_{3}$ was obtained. Subsequently, the sample was dialyzed against deionized water using a 1,000-Da cutoff membrane (Thomas Scientific, Swedesboro, NJ, USA). The dialyzate was lyophilized. We then prepared a HA solution by solubilizing HA powder in $1 \mathrm{~mL}$ of $0.1 \mathrm{M} \mathrm{mol} \mathrm{L}{ }^{-1} \mathrm{NaOH}$, followed by $\mathrm{pH}$ adjustment to 6.5 with $0.1 \mathrm{M} \mathrm{HCl}$.

\section{Microorganism used}

H. seropedicae strain HRC 54 was originally isolated from sugarcane roots [34]. It has been used as part of the sugarcane inoculant developed by Embrapa (Brazilian Enterprise for Agricultural Research). The pre-inoculum was obtained after growth in DYGS liquid medium [35] for $24 \mathrm{~h}$ at $30^{\circ} \mathrm{C}$ on an orbital shaker rotating at $150 \mathrm{rpm}$. Subsequently, $20 \mu \mathrm{L}$ of the suspension was transferred to $\mathrm{JNFb}$ liquid medium supplemented with $\mathrm{NH}_{4} \mathrm{Cl}\left(1 \mathrm{~g} \mathrm{~L}^{-1}\right)$ and then grown for $36 \mathrm{~h}$ at $34^{\circ} \mathrm{C}$ on an orbital shaker rotating at $150 \mathrm{rpm}$. Cells were pelleted by centrifugation $(4,000 \times g$ for $15 \mathrm{~min})$ and resuspended in sterilized water at cell densities of $10^{8}$ colony-forming units (cfu) $\mathrm{mL}^{-1}$. The inoculant was prepared by diluting $200 \mathrm{~mL}$ of bacterial suspension in $800 \mathrm{~mL}$ of humic acid solution at $\mathrm{pH} 6.5$ to produce a final humic acid concentration of $50 \mathrm{mg} \mathrm{C} \mathrm{L}^{-1}$ and a final bacterial concentration of $2 \times 10^{7}$ cells $\mathrm{mL}^{-1}$.

The composition of JNFb medium (per liter) was as follows: malic acid (5.0 g), $\mathrm{K}_{2} \mathrm{HPO}_{4}(0.6 \mathrm{~g}), \mathrm{KH}_{2} \mathrm{PO}_{4}(1.8 \mathrm{~g})$, $\mathrm{MgSO}_{4}{ }^{7} 7 \mathrm{H}_{2} \mathrm{O}$ (0.2 g), $\mathrm{NaCl}(0.1 \mathrm{~g}), \mathrm{CaCl}_{2}$ (0.02 g), $0.5 \%$ bromothymol blue in $0.2 \mathrm{~N} \mathrm{KOH}(2 \mathrm{~mL})$, vitamin solution $(1 \mathrm{~mL})$, micronutrient solution $(2 \mathrm{~mL}), 1.64 \%$ Fe"EDTA solution (4 mL), and $\mathrm{KOH}(4.5 \mathrm{~g})$. One-hundred milliliters of vitamin solution contained $10 \mathrm{mg}$ of biotin and $20 \mathrm{mg}$ of pyridoxol-HCl. The micronutrient solution contained (per liter) the following: $\mathrm{CuSO}_{4}(0.4 \mathrm{~g}), \mathrm{ZnSO}_{4}{ }{ }^{7} 7 \mathrm{H}_{2} \mathrm{O}(0.12 \mathrm{~g})$, $\mathrm{H}_{3} \mathrm{BO}_{3}(1.4 \mathrm{~g}), \mathrm{Na}_{2} \mathrm{MoO}_{4}{ }^{*} 2 \mathrm{H}_{2} \mathrm{O}$ (1.0 g), and $\mathrm{MnSO}_{4}{ }^{\circ} \mathrm{H}_{2} \mathrm{O}$ $(1.5 \mathrm{~g}) ; \mathrm{pH}$ was adjusted to 5.8 . For bacterial counts, we used the same media with a semisolid consistency obtained by adding $1.9 \mathrm{~g} \mathrm{~L}^{-1}$ of agar [14]. The bacterial population was determined by the most probable number technique (MPN); positive growth was recognized by the formation of a thick, white pellicle, replication was threefold, and density was expressed as the log of cell number $\mathrm{g}^{-1}$ root fresh mass after growth on JNFb N-free semisolid medium (following Döbereiner et al. [35]). The presence of $H$. seropedicae was confirmed by collecting a piece of pellicle with a platinum loop, mounting it on a slide under a coverslip, and making observations under phase contrast microscopy to determine cell shape and movement and colony appearance in JNFb solid medium, as described by Döbereiner et al. [35]. When cell shape in the pellicle material differed from that of $H$. seropedicae, we identified the microbes as native bacteria associated with maize roots.

\section{Experimental}

\section{Treatment of plants}

Maize seeds (Zea mays L. var. Dekalb 7815) were surfacesterilized by soaking in $0.5 \% \mathrm{NaClO}$ for $30 \mathrm{~min}$, followed by rinsing and then soaking in water for $6 \mathrm{~h}$. Afterward, the seeds were sown on wet filter paper and germinated in the dark at $28^{\circ} \mathrm{C}$. Four days after germination, 30 maize seedlings with root length approximately $0.5 \mathrm{~cm}$ were transferred into 2.2-L vessels previously filled with $2 \mathrm{~L}$ of one-fourth-strength Furlani nutrient solution (containing $3.527 \mu \mathrm{M}$ Ca, $2.310 \mu \mathrm{M}$ K, $855 \mu \mathrm{M}$ Mg, $45 \mu \mathrm{M}$ P, $587 \mu \mathrm{M}$ S, $25 \mu \mathrm{M}$ B, 77 Fe, $9.1 \mu \mathrm{M}$ Mn, $0.63 \mu \mathrm{M} \mathrm{Cu}, 0.83 \mu \mathrm{M}$ Mo, $2.29 \mu \mathrm{M} \mathrm{Zn}, 1.74 \mu \mathrm{M} \mathrm{Na}$, and $75 \mu \mathrm{M}$ EDTA) with inorganic $\mathrm{N}$ content adjusted to a low concentration $(100 \mu \mathrm{mol}$ $\left.\mathrm{L}^{-1}\left[\mathrm{NO}_{3}{ }^{-}+\mathrm{NH}_{4}^{+}\right]\right)$. These low levels of $\mathrm{N}$ and $\mathrm{P}$ were used to simulate the low availability in highly weathered tropical soils and to avoid the inhibition of the diazotrophic bacteria. The seedlings were fixed into a perforated Teflon support with holes of 15-mm diameter in which seeds have been fitted. The system was continuously aerated by a low flux pump normally used in aquarium systems. Four treatments ( $n=3$ pots per treatment) were prepared by supplementing the nutrient solution with the following: 1. HA (50 mg C L ${ }^{-1}$ ), 2. plant growth-promoting bacteria (PGPB) $H$. seropedicae strain HRC 54 (final bacterial suspension of $2 \times 10^{7}$ cells $\left.\mathrm{mL}^{-1}\right), 3$. humic acids plus $H$. seropedicae $(\mathrm{HA}+\mathrm{PGPB})$, and 4. control $(\mathrm{C})$, without any additions. Seedlings were collected 7, 14, and 21 days after inoculation. After 1 week, and each week thereafter, one half of the nutrient solution in each pot was replaced with fresh nutrient solution through the end of the experiment. The experiment was repeated thrice independently.

\section{Exudate collection}

Maize seedlings were removed from the pots; their roots were immersed in glass tubes filled with $50 \mathrm{~mL}$ of $0.01 \mathrm{~mol} \mathrm{~L}^{-1} \mathrm{KOH}$ for $5 \mathrm{~min}$ to remove organic anions adhering to the root surfaces. We then thoroughly washed the roots with tap water followed by a final rinse in distilled water. Complete root systems of seedlings from a single pot were inserted in a glass tube $(6.5-\mathrm{cm}$ inner diameter (i.d.) $\times 15-\mathrm{cm}$ tall) filled with $80 \mathrm{~mL}$ of ultrapure water in which to collect the root exudates. 
After $2 \mathrm{~h}$, we collected the suspensions containing root exudates and filtered them through $0.22-\mu \mathrm{m}$ filter membranes to remove root detritus and microbial cells. The filtered samples were kept frozen until we concentrated them by liquid chromatography using $10 \mathrm{~cm}$ of reverse phase (RP) C18 LiChroprep ${ }^{\oplus} \mathrm{RP}-18$ (15 to $25 \mu \mathrm{m}$; Merck Millipore, Billerica, MA, USA) as the stationary phase in an open glass column $(2.5-\mathrm{cm}$ i.d. $\times 20-\mathrm{cm}$ tall $)$. The aqueous suspension of exudate was forced through the column under low pressure provided by an aquarium pump. Compounds were eluted from the column with methanol under gravity, and the solvent was removed under low temperature $\left(4^{\circ} \mathrm{C}\right)$ under vacuum (Rocket Evaporator System, Genevac, Stone Ridge, NY, USA). We drove our exudate capture to exclude sugars and amino acids and collected mainly products of the secondary metabolism using the RP C18 column.

\section{NMR sample preparation and data collection}

For nuclear magnetic resonance (NMR) analysis, we dissolved exudate extracts in DMSO-d6 $(700 \mu \mathrm{L})$. All spectra were recorded at room temperature on a Bruker Avance DRX 500 spectrometer equipped with a 5-mm inverse detection probe (Bruker $\mathrm{GmbH}$, Rheinstetten, Germany) operating at $500.13 \mathrm{MHz}$ for $1 \mathrm{~h}$. For each sample, we recorded 360 scans (FIDs) with the following parameter settings: $64 \mathrm{k}$ data points, pulse width $8.5 \mu \mathrm{s}$ $\left(90^{\circ}\right)$, spectral width of $4,401 \mathrm{~Hz}$, acquisition time of $7.4 \mathrm{~s}$, and a relaxation delay of $1.0 \mathrm{~s}$. For spectrum processing, we used $64 \mathrm{k}$ points and applied an exponential multiplication associated with a line broadening of $0.3 \mathrm{~Hz}$. Spectra were referenced to tetramethylsilane (TMS) at $0.0 \mathrm{ppm}$. To obtain exudate profiles for each of the treatments in the study, we pooled extracts from treatment replicates and dissolved the dried methanolic extracts in $700 \mu \mathrm{L}$ of DMSO-d6. Dissolved extracts were transferred to a $5-\mathrm{mm}$ NMR tube for analysis.

\section{Principal component analysis}

The proton nuclear magnetic resonance $\left({ }^{1} \mathrm{H}\right.$ NMR) spectra were reduced to ASCII files using OACD software; the resulting data matrix was imported into The Unscrambler 10.1 software (www.camo.com). Signals corresponding to the solvent, TMS, and noise from water suppression were removed from the data set prior to statistical analysis. Principal component analysis (PCA) was performed by auto scaling the variables using normalization and calculation of the first derivative as a transformation procedure.

\section{Gas chromatography-mass spectrometry}

After NMR analysis, we analyzed the exudates by gas chromatography-mass spectrometry (GC-MS). GC separations were performed on a GCMS QP2010 Plus instrument
(Shimadzu, Tokyo, Japan) equipped with an Rtx-5MS WCOT capillary column $(30 \mathrm{~m} \times 0.25 \mathrm{~mm}$; film thickness, $0.25 \mu \mathrm{m})$ (Restek, Bellefonte, PA, USA). The exudates were derivatized by refluxing $0.30 \mathrm{mg}$ of sample for $1 \mathrm{~h}$ at $70^{\circ} \mathrm{C}$ with an excess of $\mathrm{MeOH}$ and acetyl chloride, dried under a stream of $\mathrm{N}_{2}$, followed by silylation with $100 \mu \mathrm{L}$ of $N, N$-bis[trimethylsilyl]trifluoroacetamide/1\% trimethylchlorosilane (Superchrom, Milan, Italy) in closed vials at $60^{\circ} \mathrm{C}$ for $30 \mathrm{~min}$. Chromatographic separation was achieved under the following temperature regimen: $60^{\circ} \mathrm{C}$ for $1 \mathrm{~min}$ (isothermal), rising by $7^{\circ} \mathrm{C} \min ^{-1}$ to $100^{\circ} \mathrm{C}$, and then by $4^{\circ} \mathrm{C} \mathrm{min}^{-1}$ to $320^{\circ} \mathrm{C}$, followed by $10 \mathrm{~min}$ at $320^{\circ} \mathrm{C}$ (isothermal). Helium was the carrier gas supplied at $1.90 \mathrm{~mL}$ $\min ^{-1}$, the injector temperature was $250^{\circ} \mathrm{C}$, and the split injection mode had a split flow of $30 \mathrm{~mL} \mathrm{~min}{ }^{-1}$. Mass spectra were obtained in EI mode $(70 \mathrm{eV})$ scanning in the range of $m / z 45$ to 850 with a cycle time of $1 \mathrm{~s}$. Compound identification was based on comparisons of mass spectra with the NIST library database (http://www.nist.gov/srd/ nist1a.cfm), published spectra, and real standards. Due to the large variety of compounds with different chromatographic responses that we detected, external calibration curves for quantitative analysis were built by mixing methyl esters and/or methyl ethers of the following molecular standards: tridecanoic acid, octadecanol, 16-hydroxyhexadecanoic acid, docosandioic acid, $\beta$-sitosterol, and cinnamic acid. Increasing quantities of standard mixtures were loaded into a quartz boat and moistened with $0.5 \mathrm{~mL}$ of tetramethylammonium hydroxide (TMAH) solution (25\% in methanol).

\section{Results}

Root tissue colonization by $H$. seropedicae strain HRC54

We examined the population dynamics of $H$. seropedicae strain HRC 54 associated with maize roots 7, 14, 21, and 30 days after inoculation (Figure 1). For all inoculation treatments (PGPB and $\mathrm{HA}+\mathrm{PGPB})$, the root-associated bacterial numbers were higher than those of uninoculated plants (controls). Cell shape and colony appearance confirmed the presence of Herbaspirillum in the pellicle harvested from the highest dilution, thereby indicating the effectiveness of inoculation.

Maize plants treated with only HA had higher bacterial numbers associated with roots than control plants. Even after seed surface disinfection, diazotrophic bacteria were recoverable from treated plants; these microbial populations were naturally occurring $\mathrm{N}$ fixers associated with maize seeds. They were clearly different from $H$. seropedicae (under phase contrast microscopy) in cell shape and colony form when grown in JNFb solid medium (data not shown).

We compared treatments PGPB and HA + PGPB, observing higher numbers of root-associated viable $H$. seropedicae cells in the latter. This result is qualitatively similar 


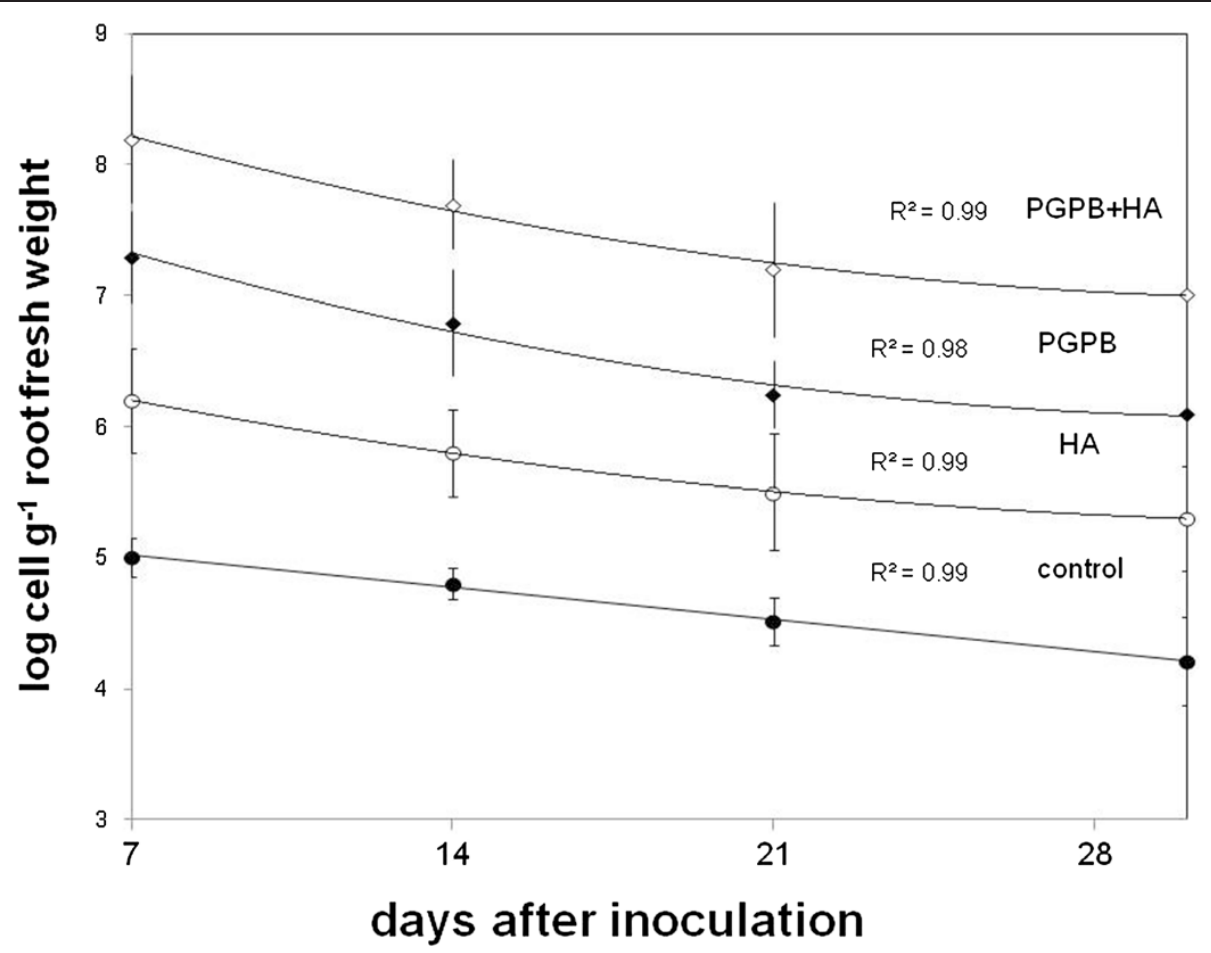

Figure 1 Number of bacterial cells (log cells $\mathrm{g}^{-1}$ fresh tissue) on roots of maize seedlings during different growth times. Treatments: control plants, $\log 10^{9}$ cells $\mathrm{mL}^{-1}$ of Herbaspirillum seropedicae strain HRC 54, humic acids isolated from vermicompost $\left(50 \mathrm{mg} \mathrm{L}^{-1}\right)$, and bacteria plus humic acids. The values represent the mean \pm standard deviation.

to those obtained previously [9], indicating that HA per se increase the numbers of $H$. seropedicae cells colonizing root tissues and help maintain large populations in inoculated plants over protracted time periods (Figure 1). We identified similar tendencies for natural diazotrophs, whose population sizes were enhanced by HA application (in comparison with populations in control plants).

\section{Mass of root exudates}

The yields of exudates retained by the procedures used are depicted in Figure 2. Over the course of the experiment, the quantities of exudates collected across sampling occasions and treatments ranged broadly between 0.25 and $4.00 \mathrm{mg} \mathrm{g}^{-1}$ root dry weight, making it difficult to identify any treatment effects.

\section{${ }^{1} \mathrm{H}$ NMR and PCA}

Nuclear magnetic resonance $\left({ }^{1} \mathrm{H}\right.$ NMR) coupled with multivariate analysis (PCA) enabled rapid discrimination among root exudate samples. The ${ }^{1} \mathrm{H}$ NMR spectra of the exudate compounds eluted from the RP C18 column with methanol on days 7,14 , and 21 are depicted in Figures $3,4,5$, respectively; the main ${ }^{1} \mathrm{H}$ chemical shifts are detailed in Table 1. Visual inspection of the ${ }^{1} \mathrm{H}$ NMR spectra revealed a predominance of signals in the carbohydrate region ( 2.5 to $4.5 \mathrm{ppm}$ ) followed in rank order by signals in the aliphatic/organic acid ( 0.0 to $3.0 \mathrm{ppm}$ ) and aromatic (5.0 to $8.0 \mathrm{ppm}$ ) regions. NMR spectra revealed different exudate profiles between treated and control plants. On day 7 , the control spectrum contained several chemical shifts in the aliphatic region, with a small signal at $0.96 \mathrm{ppm}$ and a short, intense signal at $1.24 \mathrm{ppm}$. The sugar region had a main signal at $3.71 \mathrm{ppm}$ and other signals of low intensity at 3.41 and $3.93 \mathrm{ppm}$. In the aromatic region, it was possible to

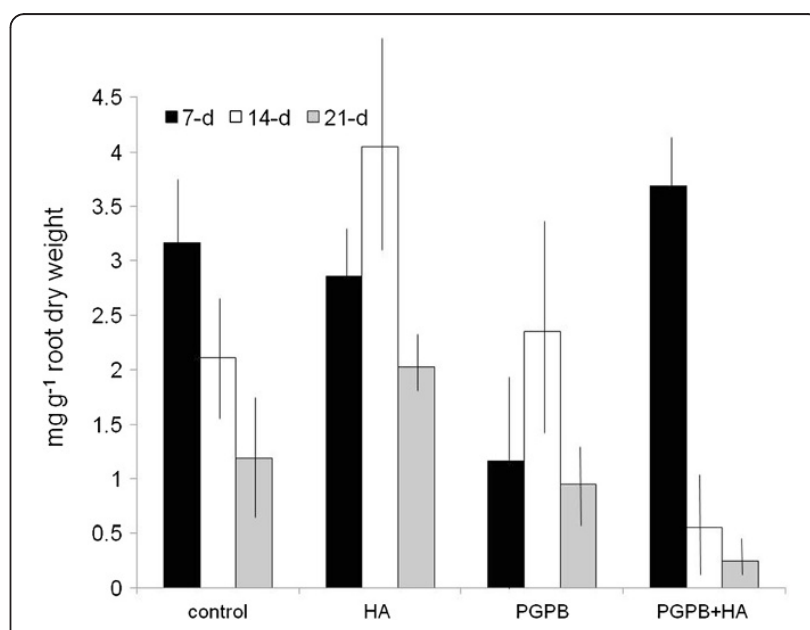

Figure 2 The yield of exudates at 7, 14, and 21 days after treatments. The values represent the mean \pm standard deviation. 


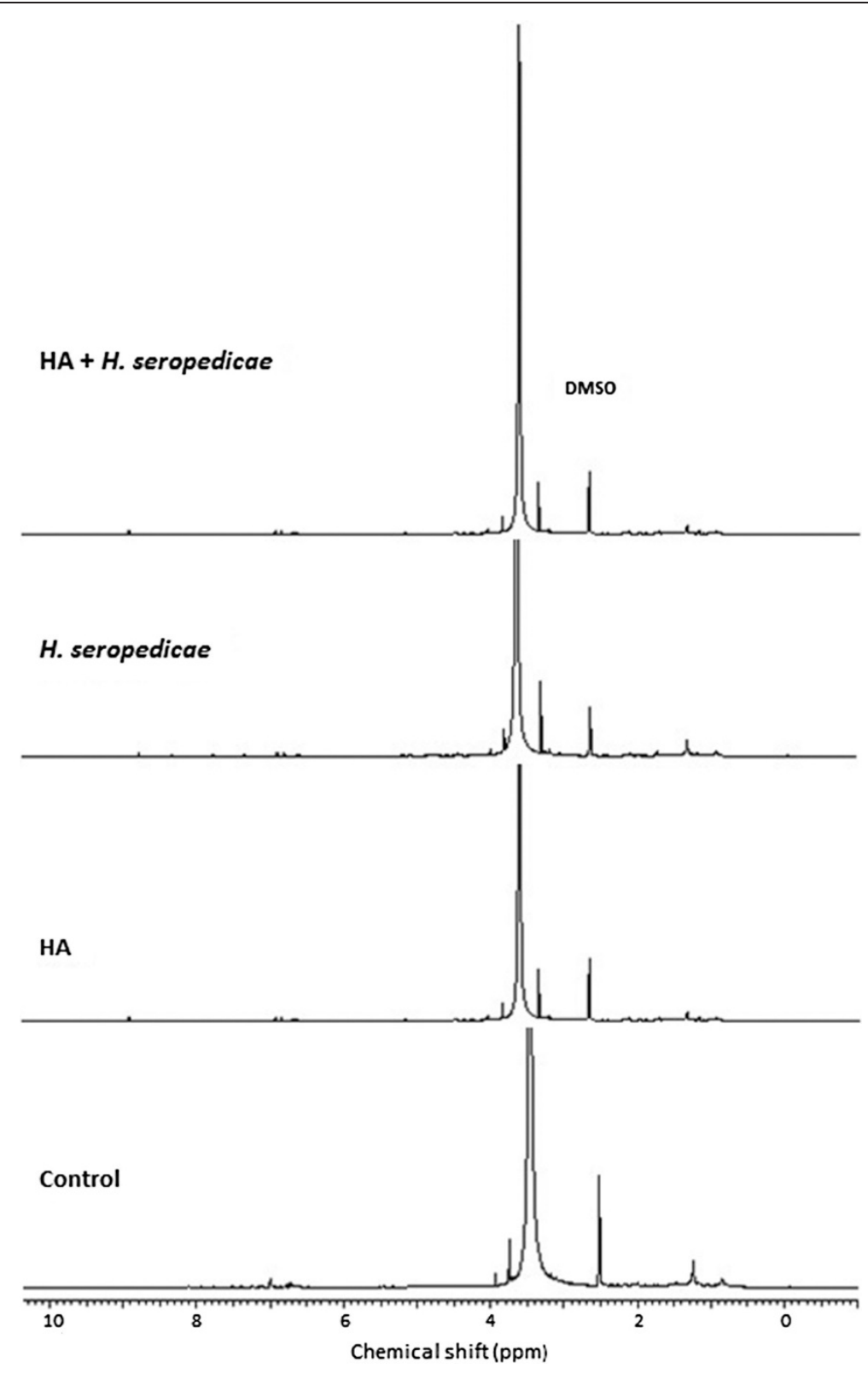

Figure 3 Spectra of root exudate at 7 days.

observe small signals in the 6.69 to $6.74 \mathrm{ppm}$ region and at $7.0 \mathrm{ppm}$. The signals at $1.24 \mathrm{ppm}$ may have been related to the presence of $\mathrm{CH}_{3}$ compounds of aliphatic acids and $\mathrm{BCH}_{3}$ in amino acids of maize extracts. The strong absorption at $3.71 \mathrm{ppm}$ may be attributed to the presence of glycosylated compounds ( $\beta$-Glc and $\alpha$-Glc). The signals at $6.7 \mathrm{ppm}$ are typical of hydroxybenzoic acids, such as cinnamic and protocatechuic acids. Tryptophan, histidine, and gallic acids have signals near $7.0 \mathrm{ppm}$. Treatment of maize seedlings with HA changed the region of aliphatic absorption, and additional signals were observed at $0.84,0.88$, and $1.10 \mathrm{ppm}$. These signals were also recorded for exudates from plants treated with
H. seropedicae (treatment PGPB), which had an additional signal at $1.64 \mathrm{ppm}$ that was absent in control exudates. Additional signals were present at 1.08, 1.20, and $2.0 \mathrm{ppm}$ in exudates from treatment $\mathrm{HA}+\mathrm{PGPB}$. The exudate spectrum from seedlings treated with HA alone had an additional absorption at $3.93 \mathrm{ppm}$ attributable to sucrose $(3.48,3.84,3.90,4.22$, and $5.42 \mathrm{ppm})$ and/or lysine (since a typical signal was also observed at $\left.1.64 \mathrm{ppm}\left[\delta \mathrm{CH}_{2}\right]\right)$. Exudates from seedlings in treatment $\mathrm{HA}+\mathrm{PGPB}$ had additional though very small signals in the aromatic region in the range 6.34 to $6.62 \mathrm{ppm}$ and a very small signal at $8.52 \mathrm{ppm}$. Compounds similar to niacin have signals in this region. 


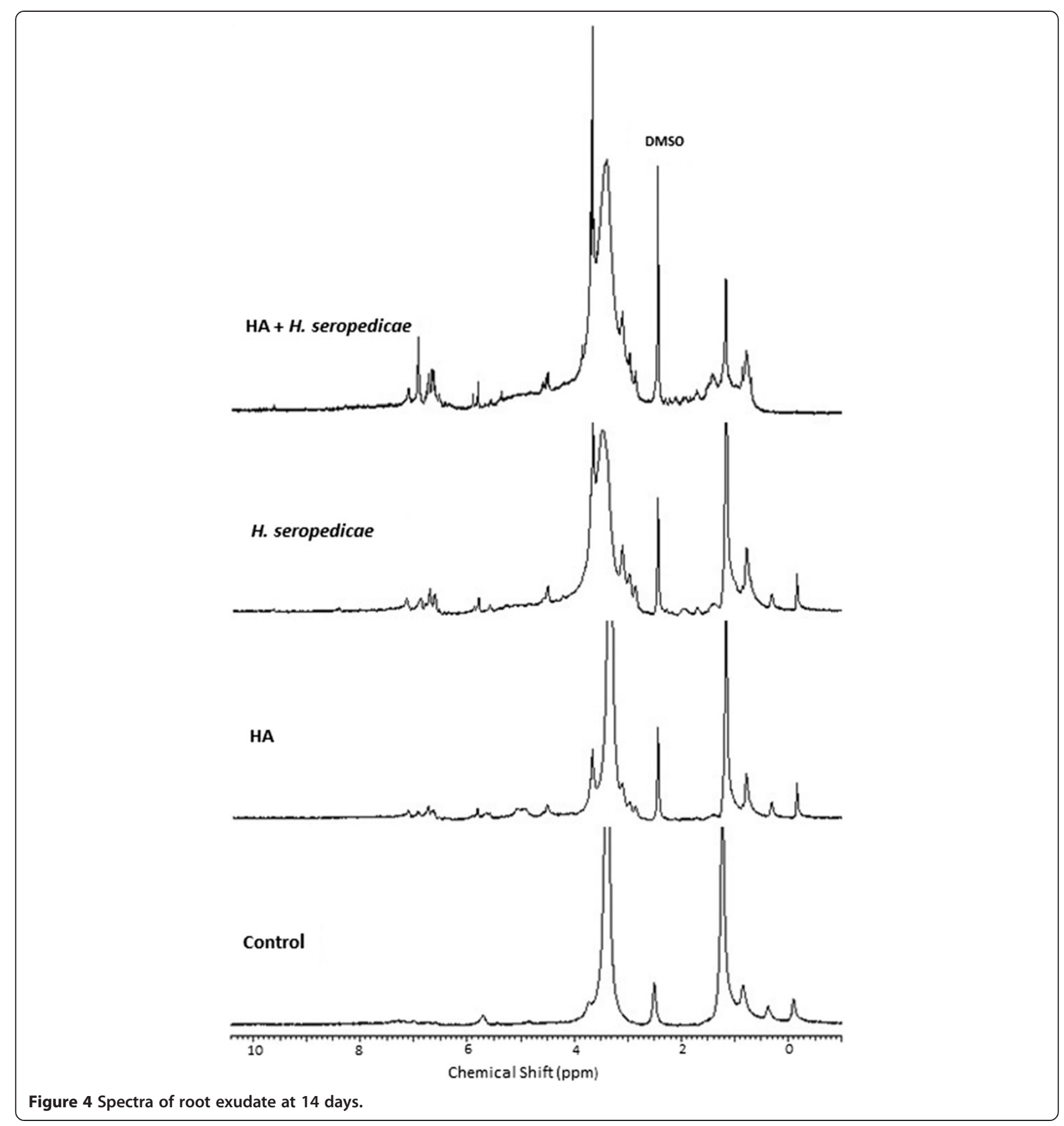

The profiles of exudates collected on day 14 were very different from those collected on day 7. The intensity of the signal at $1.23 \mathrm{ppm}$ was enhanced in all spectra, with the highest intensity in the exudates collected from seedlings in treatment PGPB. We observed very weak signals related to aromatic compounds in the control exudate spectrum on day 14, with just one visible signal at $5.70 \mathrm{ppm}$. In contrast, signals for this region were very strong in treatment $\mathrm{HA}+\mathrm{PGPB}$ exudates. In treatment $\mathrm{HA}$, there was a diversity of signal shoulders in regions
4.99 to $5.13,5.65$ to 5.71 , and 6.69 to $6.80 \mathrm{ppm}$ and individual signals at 6.99 and $7.18 \mathrm{ppm}$. Treatment PGPB exudates had clearer signals in this region than treatment HA; treatment PGPB had well-resolved signals at $5.64,5.85,6.07,6.77,6.93$, and $7.20 \mathrm{ppm}$. This spectrum was marked by weak main signals at 3.54 and $3.72 \mathrm{ppm}$. There were additional signals in the aliphatic region at $1.48,1.77$, and 2.03 , which were not present in the spectra from the controls and treatment HA. The characteristics of the exudate spectra were similar between 


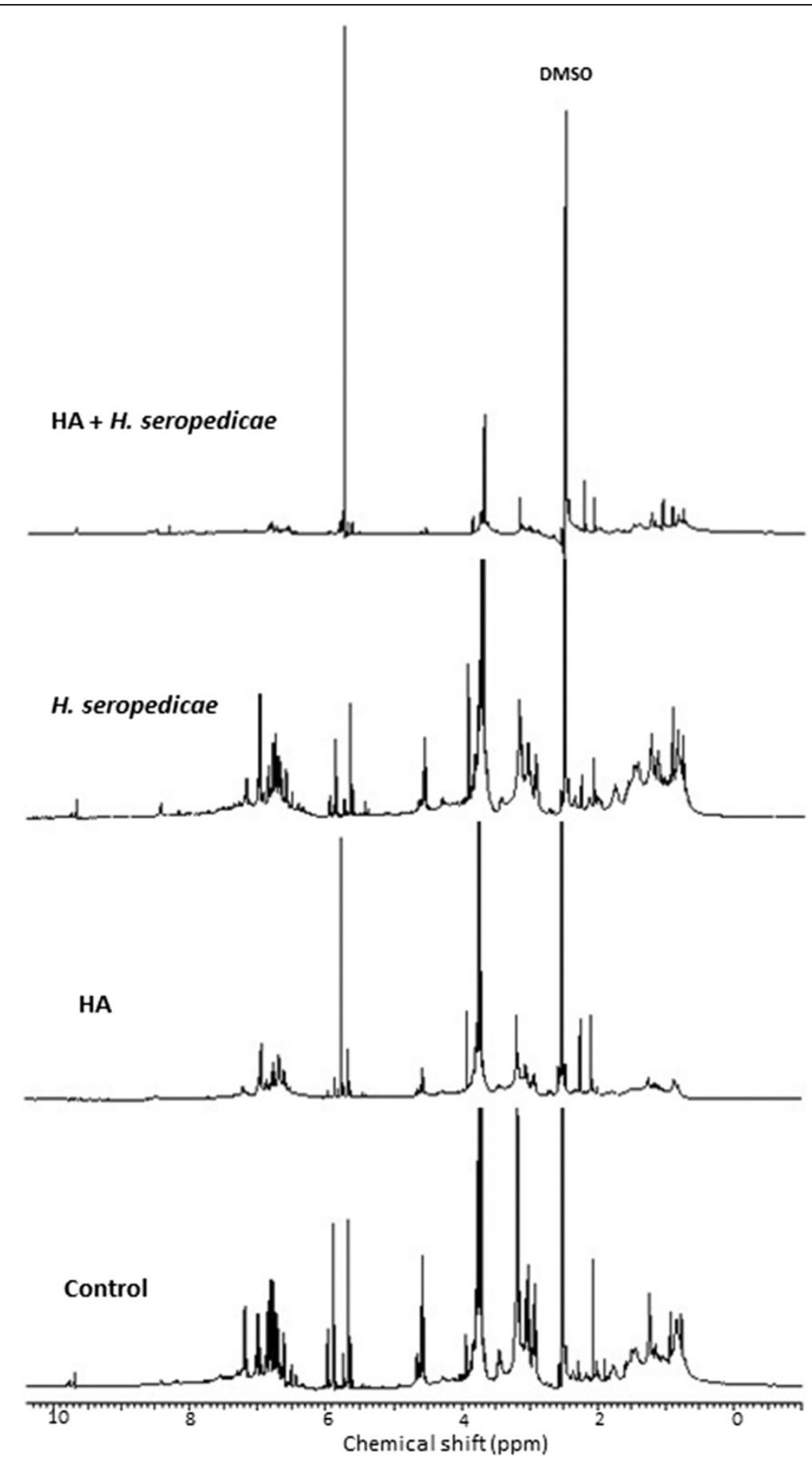

Figure 5 Spectra of root exudate at 21 days.

treatments PGPB and HA + PGPB, i.e., a strong modification in the aromatic region including a sharp signal at $6.98 \mathrm{ppm}$. However, in treatment $\mathrm{HA}+\mathrm{PGPB}$, there were changes in the sugar region including an increased intensity in the signal at $3.72 \mathrm{ppm}$.

On day 21 after inoculation, seedlings were less dependent on seed reserves and the exudate profiles were modified by the treatments (Figure 2, Table 1). The spectra were more complex than those in earlier exudates; they were characterized by an abundance of signals. Control exudates had a wide range of small signals in the aliphatic region. In the control spectra from days 7 and 14, the main signal in this region was at $2.08 \mathrm{ppm}$. Additional signals occurred in the sugar region between 
Table 1 1H chemical shift

\begin{tabular}{|c|c|c|c|c|c|c|c|c|c|c|c|c|}
\hline & \multicolumn{3}{|c|}{ Control } & \multicolumn{3}{|c|}{ HA } & \multicolumn{3}{|c|}{ PGPB } & \multicolumn{3}{|c|}{$\mathrm{HA}+\mathrm{PGPB}$} \\
\hline & 7 & 14 & 21 & 7 & 14 & 21 & 7 & 14 & 21 & 7 & 14 & 21 \\
\hline \multirow[t]{25}{*}{ Aliphatic } & 0.96 & 0.10 & 0.10 to 0.72 & 0.84 & 0.38 & 0.68 & 0.84 & 0.38 & 0.01 to 0.59 & 1.08 & 0.77 & 0.78 \\
\hline & 1.24 & 0.38 & 0.77 & 0.93 & 0.85 & 0.70 & 0.93 & 0.85 & 0.62 & 1.10 & 0.85 & 0.82 to 0.89 \\
\hline & & 0.85 & 0.80 to 1.39 & 1.10 & 1.23 & 0.71 & 1.10 & 1.23 & 0.64 & 1.20 & 1.23 & 0.94 \\
\hline & & 1.23 & 1.44 & 1.24 & & 0.73 to 1.00 & 1.24 & 1.48 & 0.65 & 1.24 & 1.49 & 0.95 \\
\hline & & & 1.47 to 1.50 & 1.64 & & 1.03 to 1.22 & 1.64 & 1.77 & 0.70 & 2.0 & 2.29 & 1.07 to 1.10 \\
\hline & & & 1.54 to 1.68 & & & 1.25 & & 2.03 & 0.73 & 3.05 & 2.35 & 1.17 to 1.28 \\
\hline & & & 1.76 & & & 1.28 to 1.54 & & & 0.77 & 3.18 & 2.92 to 3.17 & 1.41 to 1.54 \\
\hline & & & 1.78 & & & 1.57 & & & 0.80 to 0.86 & & & 2.09 \\
\hline & & & 1.81 & & & 1.60 to 2.06 & & & 0.90 to 1.24 & & & 2.24 \\
\hline & & & 1.84 & & & 2.09 & & & 1.34 & & & 2.46 to 2.57 \\
\hline & & & 1.86 to 2.39 & & & 2.10 & & & 1.35 & & & 2.93 \\
\hline & & & 2.42 & & & 2.14 to 2.22 & & & 1.39 & & & 2.95 \\
\hline & & & 2.43 & & & 2.25 & & & 1.44 & & & 2.99 to 3.28 \\
\hline & & & 2.47 & & & 2.28 & & & 1.48 to 1.51 & & & \\
\hline & & & 2.52 & & & 2.30 & & & 1.54 & & & \\
\hline & & & 2.56 & & & 2.34 to 2.42 & & & 1.57 & & & \\
\hline & & & 2.57 & & & 2.47 & & & 1.60 to 1.69 & & & \\
\hline & & & 2.69 & & & 2.52 & & & 1.76 & & & \\
\hline & & & 2.75 to 3.36 & & & 2.57 & & & 1.77 & & & \\
\hline & & & & & & 2.60 to 2.69 & & & 1.80 & & & \\
\hline & & & & & & 2.72 to 3.23 & & & 1.84 & & & \\
\hline & & & & & & & & & 1.87 to 2.42 & & & \\
\hline & & & & & & & & & 2.47 & & & \\
\hline & & & & & & & & & 2.52 & & & \\
\hline & & & & & & & & & 2.56 to 3.36 & & & \\
\hline \multirow[t]{6}{*}{ Sugars } & 3.47 & 3.39 & 3.38 to 4.72 & & 3.40 & 3.27 to 3.61 & 3.50 & & 3.40 to 3.56 & 3.44 & 3.46 & 3.40 \\
\hline & 3.71 & 3.73 & 4.92 & 3.74 & 4.56 & 3.66 & & 3.54 & 3.66 to 5.00 & 3.65 & 3.73 & 3.42 \\
\hline & 3.93 & & & 3.93 & 4.99 to 5.13 & 3.68 & & 3.72 & & 4.26 & 4.56 & 3.53 \\
\hline & & & & & & 3.71 to 4.65 & & 4.56 & & & 4.58 & 3.56 to 3.82 \\
\hline & & & & & & 4.67 to 4.99 & & 4.65 & & & 4.64 & 3.88 \\
\hline & & & & & & & & & & & 4.66 & \\
\hline \multirow[t]{14}{*}{ Aromatic } & 6.69 to 6.74 & 5.70 & 5.45 & 6.71 & 5.65 to 5.71 & 5.00 to 6.16 & 6.51 & 5.64 & 5.01 to 6.80 & 6.34 to 6.62 & 5.65 & 5.66 \\
\hline & 7.0 & & 5.61 & 7.01 & 5.88 & 6.19 to 6.54 & 6.65 & 5.85 & 6.85 & 8.52 (very low) & 5.87 & 5.72 \\
\hline & & & 5.63 & & 6.69 to 6.80 & 6.57 to 6.90 & & 5.94 & 6.87 & & 5.96 & 5.77 \\
\hline & & & 5.66 & & 6.99 & 6.94 to 7.61 & & 6.67 & 6.89 to 7.04 & & 6.0 & 5.82 \\
\hline & & & 5.68 & & 7.18 & 7.71 & & 6.77 & 7.07 & & 6.70 & 6.82 \\
\hline & & & 5.70 to 5.72 & & & 7.73 & & 6.93 & 7.10 to 9.49 & & 6.73 & 6.83 \\
\hline & & & 5.75 & & & 7.87 & & 7.20 & 9.64 & & 6.98 & 8.34 \\
\hline & & & 5.83 & & & 8.00 & & & 9.69 to 9.99 & & 7.16 & \\
\hline & & & 5.88 to 5.93 & & & 8.05 & & & & & & \\
\hline & & & 5.97 & & & 8.34 & & & & & & \\
\hline & & & 5.98 & & & 8.45 & & & & & & \\
\hline & & & 6.34 & & & 8.49 & & & & & & \\
\hline & & & 6.42 to 8.60 & & & 9.74 & & & & & & \\
\hline & & & 9.69 to 9.78 & & & & & & & & & \\
\hline
\end{tabular}


3.03 and $3.45 \mathrm{ppm}$, including a sharp signal at $3.18 \mathrm{ppm}$. The main absorption in this region occurred at 3.73 ppm, as in earlier exudates. Signals between 4.55 and $4.67 \mathrm{ppm}$ were very minor or absent in exudates from days 7 and 14, but much higher and with greater definition by day 21 , which was also the case for signals in the aromatic region (6.50 to $7.19 \mathrm{ppm}$ ). Additional small signals occurred at 9.69, 9.76, and $9.78 \mathrm{ppm}$. The exudate profile from treatment HA was generally quite similar to that of the control, but significant differences were apparent. For example, there was no sharp, high-intensity signal at $2.25 \mathrm{ppm}$ in the control, but this was observable in treatment HA exudates, which also had a very intense signal at $5.57 \mathrm{ppm}$ (this was the main signal in treatment $\mathrm{HA}+$ PGPB spectra but a very minor one in treatment PGPB and in the control). On day 21, the spectra of exudates were closely similar between treatment PGPB and the control.

Similarities and dissimilarities among treatments and experimental days were examined by PCA analysis (Figure 6). PC1 (89\%) and PC2 (10\%) accounted for 99\% of the total variance in the ${ }^{1} \mathrm{H}$ NMR data set. Symbols in the PCA plot are identified by treatment codes and days of exudate collection. Three groups of symbols are apparent in the Cartesian two-dimensional space of axes PC1 and PC2; these correspond to the three occasions of exudate collection. The day 7 group is located in the positive sector of the $\mathrm{PC} 1$ axis and in the negative sector of the PC2 axis. Positive values of $\mathrm{PC} 1$ and the loading coefficient responsible for this distinction are large for the carbohydrate ${ }^{1} \mathrm{H}$ NMR region (3 to $4 \mathrm{ppm}$ ). HA + PGPB symbols for the day 14 fall in the negative sector of $\mathrm{PC} 2$, but other treatment symbols for this collection day fall in the positive sector of this axis. HA and PGPB symbols cluster together; the control treatment had high values of aliphatic moieties (0 to $2 \mathrm{ppm}$ ). On day 21, the HA + PGPB and HA treatments had very different exudate compositions with elevated aromatic and aliphatic contents, respectively. The control and PGPB treatment clustered together.

Overall, the PCA analysis aided interpretation and comparisons in the data set. Thus, on day 7, exudate compositions were not significantly different among treatments, but significant differences were observed on days 14 and 21. This trend was corroborated by GC-MS analysis. The chromatograms are available in the supplementary data (Additional files 1, 2, and 3). Main exudates retained in the RP C18 column and identified by GC-MS are indicated in Table 2. On day 7, the chromatograms were closely similar; the main compounds were nitrogenous carbohydrate derivatives and fatty acids (as methyl esters). Nevertheless, there were some differences among treatments on day 7. For example, exudation of carbohydrate compounds by root seedlings in treatment $\mathrm{HA}+\mathrm{PGPB}$ exceeds those in other treatments (Table 2). The chromatogram peaks of these carbohydrate compounds for treatments PGPB and HA were twice as high as that for the control; we identified galacto, gluco, and mannose pyranoside structures in these peaks. D-glucopyranoside moieties associated with aromatic rings were also found in control exudates, but 1,6- $\beta$-glucose was found only in exudates from plants in treatment HA. The quantities and diversities of nitrogenous compounds on day 7 were also greater in treatment HA and PGPB exudates than in the controls (Table 2). Benzilamines, polyamines, pyrrol derivatives, amino acid complexes, and nucleotide derivatives were included in this group of compounds. Benzilamines and polyamines were exuded only in treatments HA and HA + PGPB. Nitrogenous compounds from the phenylalanine pathway were present; these included pyrimidinedione, pyrrole-3-carboxylic acid and a derivative from $p$-coumaric hydrolysis with a retention time at $28.91 \mathrm{~min}$ (identified as caffeine). Structures derived from adenosine were found in all treatments, but those from purine were found only in treatment PGPB. Overall, treatment HA + PGPB induced the largest and most diverse exudation of nitrogenous compounds.

Fatty acids comprised the second largest class of compounds exuded on day 7. Unlike nitrogenous compounds, treatments PGPB and HA + PGPB induced exudations of only small quantities of fatty acids (in comparison with treatment HA and the control). Chromatogram peak areas for fatty acids were elevated by $52 \%$ in treatment HA in comparison with the control on day 7 . The main fatty acid in the HA exudate was hexadecanoic acid (palmitic acid). Stearic acid (octadecenoic) was exuded only by control plants, while tridecanoic acid and eicosanoic acid (also known as arachidic acid), which are minor constituents of corn oil, were found only in treatment HA exudates. Palmitic and stearic acids were found in treatment PGPB exudates. Although GC-MS is not particularly appropriate for short-chain organic acid identification, we did observe the presence of propenoic acid associated with long-chain carbon compounds in control and treatment HA exudates; we also detected succinic acid associated with aromatic moieties in treatment HA + PGPB. Benzenedicarboxylic acid was the main aromatic exudate. The steroid isosteviol was found in all exudates. Other steroids, such as cyclolanostane and androstane, were found in exudates produced in treatments HA, PGPB, and HA + PGPB.

The main classes of compounds were similar among days 7, 14, and 21 (Table 2), but the diversity of compounds diminished progressively as the seedlings grew. There were differences among the treatments: on day 14, nitrogenous compounds were still abundant in the HA, PGPB, and HA + PGPB treatment exudates; the concentrations were threefold to fourfold higher than those in the control. Nucleotide derivatives were observed on day 7 , but not later. Products from phenylalanine and pyridines were exuded in treatments PGPB and HA + PGPB, 

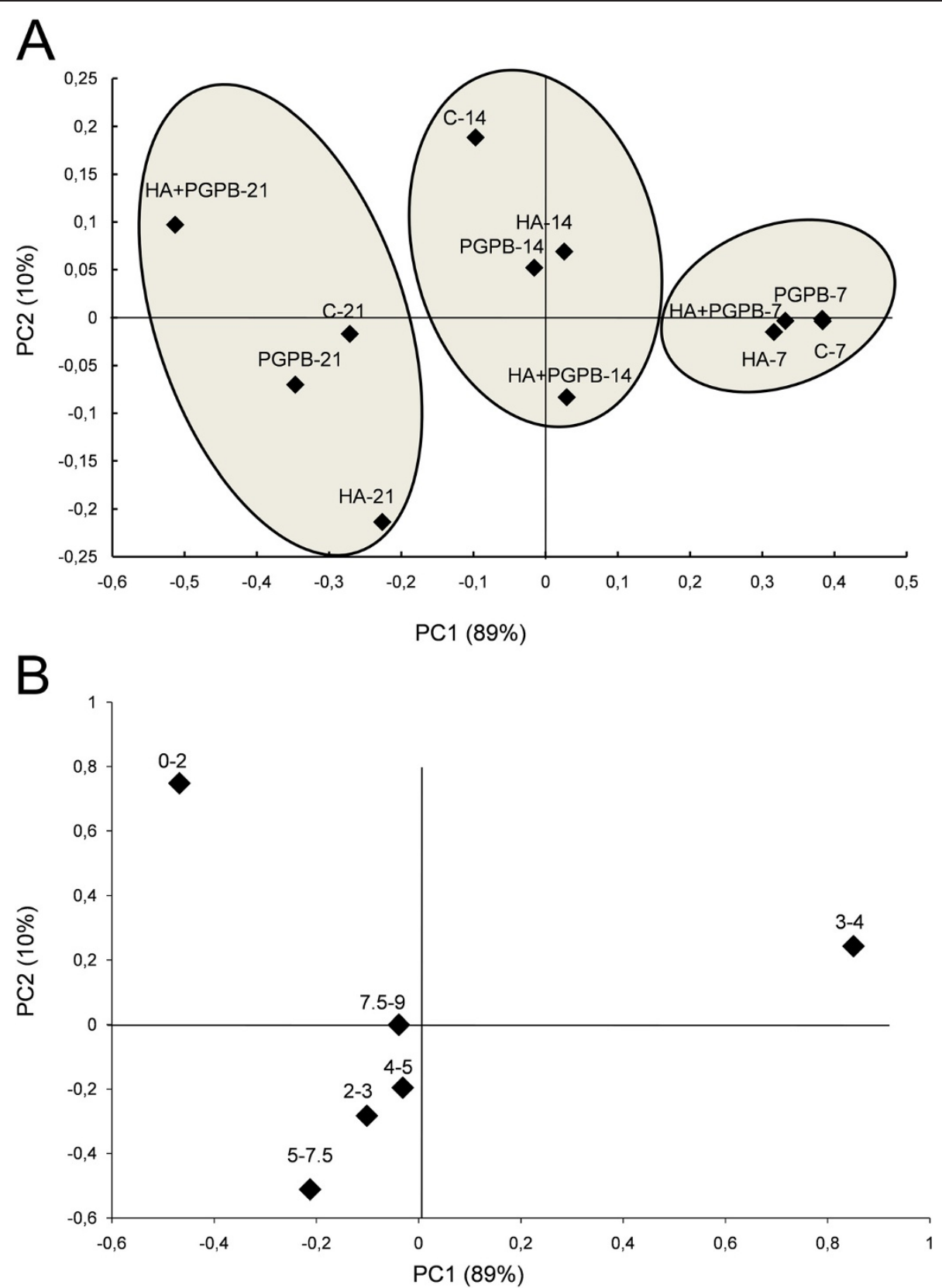

Figure 6 PCA scores and PCA loading plot. (A) PCA scores, indicating good separation in different groups according to treatments and days of treatments. (B) PCA loading plot. Position of the variables along the PCs indicates their importance for that PC.

while phenyl cyanate and pyrrol derivatives were found in treatment HA exudates. The compounds present in exudates from treatments PGPB and HA + PGPB were closely similar (Table 2), although benzene, 1-isocyanato-4-methoxy, was exuded only in treatment PGPB and carbonic acid, monoamine, $N$-(2,4-dimethoxyphenyl)-, and butyl ester only in treatment HA + PGPB. Exudations of carbohydrates were elevated in treatments $\mathrm{HA}$ and PGPB. These exudates contained compounds we had identified on day 7. However, quantities of carbohydrate derivatives were reduced in treatment $\mathrm{HA}+\mathrm{PGPB}$ and absent in control seedling exudates.

Hexadecanoic and octadecanoic acids were the main fatty acids occurring as methyl esters in control exudates. These compounds also occurred in other treatments, but the diversity was greatest in PGPB and HA + PGPB treatments. However, on day 7, the quantities and diversity were highest in treatment HA. As on day 7 , products of the isosteviol reaction occurred in all exudates; another steroid (androstane derivative) was also 
Table 2 Compounds identified by GC-MS analysis

\begin{tabular}{|c|c|c|c|c|c|c|c|c|c|c|c|c|c|}
\hline \multirow[t]{2}{*}{$\begin{array}{l}\text { Retention } \\
\text { time (min) }\end{array}$} & \multirow[t]{2}{*}{ Compound class } & \multicolumn{3}{|c|}{ Control } & \multicolumn{3}{|c|}{ HA } & \multicolumn{3}{|c|}{ H. seropedicae } & \multicolumn{3}{|c|}{$\begin{array}{l}\mathrm{HA}+ \\
\text { H. seropedicae }\end{array}$} \\
\hline & & 7 & 14 & 21 & 7 & 14 & 21 & 7 & 14 & 21 & 7 & 14 & 21 \\
\hline & \multicolumn{13}{|l|}{ Nitrogenous compounds } \\
\hline 9.575 & $\begin{array}{l}\text { 3-Butenoic acid, 3-methoxy-4-nitro-, } \\
\text { methyl ester, (E) }\end{array}$ & nd & nd & nd & nd & 3.82 & nd & nd & nd & nd & nd & nd & nd \\
\hline 14.754 & Benzene, 1-isocyanato-4-methoxy & nd & nd & nd & nd & 0.82 & nd & nd & 0.83 & nd & 0 & nd & nd \\
\hline 20.618 & 3,4-Dimethoxy-6-amino toluene & 8.54 & 2.75 & 0 & 8.93 & 4.78 & 6.08 & 7.41 & 5.00 & 9.70 & 12.14 & 5.43 & 3.35 \\
\hline 21.787 & $\begin{array}{l}\text { 1H-Pyrrole-3-carboxylic acid, } \\
\text { 5-formyl-1-(methoxymethyl)-, methyl ester }\end{array}$ & 4.22 & nd & nd & nd & 1.21 & nd & nd & nd & 2.65 & nd & nd & nd \\
\hline 21.795 & 3,4,5-Trimethoxybenzylamine & nd & nd & nd & 5.11 & nd & nd & 3.47 & 1.18 & 1.18 & 4.56 & 1.21 & nd \\
\hline 24.873 & 2,5-Dimethoxyphenyl isocyanate & 11.41 & 7.41 & 0 & 16.78 & 13.18 & 24.30 & 14.36 & 10.64 & 48.74 & 18.82 & 24.19 & 16.91 \\
\hline 25.952 & 2,4-Dimethoxyphenylamine, N-ethoxycarbonyl- & 0.48 & nd & nd & 0 & nd & nd & nd & 0.26 & 0.57 & 0.68 & 0.70 & nd \\
\hline 26.019 & 9H-Purin-6-amine, N,N,9-trimethyl & 2.15 & nd & nd & 1.30 & nd & nd & 1.97 & nd & nd & 1.84 & nd & nd \\
\hline 26.982 & 4-(Diethylamino)salicylaldehyde & nd & nd & nd & nd & nd & nd & nd & nd & 2.87 & nd & nd & nd \\
\hline 27.134 & 2,3,4-Trimethoxyphenylacetonitrile & nd & nd & nd & nd & nd & nd & nd & nd & 0.94 & nd & nd & nd \\
\hline 28.503 & $\begin{array}{l}\text { Bicyclo[2.2.1] heptane-2-acetamide, } \\
\mathrm{N} \text {-(1,3-dihydro-5,6-dimethoxy-3-oxo- } \\
\text { 4-isobenzofuranyl) }\end{array}$ & 3.04 & nd & nd & 4.69 & nd & 5.30 & 3.51 & nd & 13.17 & 5.26 & nd & 3.32 \\
\hline 28.703 & 3,4,5-Trimethoxyphenyl cyanate & nd & nd & nd & nd & 2.23 & nd & nd & nd & nd & nd & nd & nd \\
\hline 28.709 & Tris(2,4,6-dimethylamino)pyrimidine & nd & nd & nd & nd & nd & nd & nd & 1.75 & nd & nd & 3.34 & nd \\
\hline 28.915 & Caffeine & nd & nd & nd & 0.48 & nd & nd & nd & nd & nd & nd & nd & nd \\
\hline 29.340 & Acetamide, N-[2-(3,4-dimethoxyphenyl)ethyl] & nd & nd & nd & nd & nd & nd & nd & 0.89 & 4.06 & nd & nd & nd \\
\hline 29.346 & $\begin{array}{l}\text { 3-Pyridinecarboxamide, 4-(methoxymethyl)- } \\
\text { 6-methyl-2-propoxy- }\end{array}$ & nd & nd & nd & nd & nd & 0.53 & nd & nd & nd & nd & nd & 1.49 \\
\hline 29.537 & 1,3-Benzenediamine, $N, N^{\prime}$-diethyl & nd & nd & nd & nd & 0.41 & nd & nd & nd & nd & nd & nd & nd \\
\hline 30.534 & $\begin{array}{l}\text { Carbonic acid, monoamide, } \\
N \text {-(2,4-dimethoxyphenyl)-, butyl ester }\end{array}$ & nd & nd & 9.55 & nd & nd & nd & nd & nd & nd & nd & nd & nd \\
\hline 30.774 & $\begin{array}{l}\text { 3-(2-Ethoxycarbonyl-ethyl)-4-methyl-1H-pyrrole- } \\
\text { 2-carboxylic acid, ethyl ester }\end{array}$ & nd & nd & nd & nd & 12.62 & nd & nd & nd & nd & nd & nd & nd \\
\hline 30.775 & $\begin{array}{l}\text { Carbonic acid, monoamide, } \\
\text { N-(2,4-dimethoxyphenyl)-, butyl ester }\end{array}$ & nd & nd & nd & nd & nd & nd & nd & nd & nd & nd & 6.93 & nd \\
\hline 30.801 & $\begin{array}{l}\text { Propanamide, 3-amino-N-(2,5-dimethoxyphenyl)- } \\
\text { 3-(hydroxyimino)- }\end{array}$ & nd & nd & nd & nd & nd & nd & nd & 14.99 & nd & nd & nd & nd \\
\hline 26.134 & Phenol, 4-(aminomethyl)-2-methoxy & nd & nd & nd & nd & 0.33 & nd & nd & nd & nd & nd & nd & nd \\
\hline 30.741 & $\begin{array}{l}\text { 1,5-Bis[veratrylaminomethyl]-2,6- } \\
\text { dihydroxynaphthalene }\end{array}$ & nd & 1.25 & nd & nd & nd & nd & nd & nd & nd & nd & nd & nd \\
\hline 30.952 & 3H-Purin-6-amine, N,N,3-trimethyl & nd & nd & nd & nd & nd & nd & 0.61 & nd & nd & 0.58 & nd & nd \\
\hline 31.834 & Benzeneethanamine, $\mathrm{N}$-acetyl-2,3,4,5-tetramethoxy & nd & nd & nd & nd & nd & nd & nd & 2.83 & nd & nd & nd & nd \\
\hline 32.132 & Acetamide, N-(3,4,5-trimethoxyphenethyl) & nd & nd & nd & nd & nd & nd & nd & nd & 0.91 & nd & nd & 0.40 \\
\hline 35.077 & Uridine, 2'-deoxy-3-methyl-3',5'-di-O-methyl- & nd & nd & nd & nd & nd & nd & nd & nd & nd & 0.19 & nd & nd \\
\hline 35.926 & Cytidine, $\mathrm{N}$-methyl-, 2',3',5'-trimethyl ether & 0.62 & nd & nd & 1.44 & nd & nd & 1.52 & nd & nd & 0.55 & nd & nd \\
\hline 36.019 & Thymidine, 2'-deoxy-N,O,O-trimethyl- & 0.91 & nd & nd & 1.62 & nd & nd & 2.24 & nd & nd & 3.37 & nd & nd \\
\hline 37.792 & N-[12-Aminododecyl]aziridine & 0.52 & nd & nd & 0.58 & nd & nd & 0 & nd & nd & 0.95 & nd & nd \\
\hline 41.125 & Adenosine, 2'-deoxy-N,N,O,O-tetramethyl- & nd & nd & nd & 0.65 & nd & nd & 1.60 & nd & nd & 2.11 & nd & nd \\
\hline 42.007 & Adenosine, 3'-amino-3'-deoxy-N,N-dimethyl & nd & nd & nd & 0.20 & nd & nd & 0.46 & nd & nd & 0.66 & nd & nd \\
\hline & & nd & nd & nd & nd & nd & nd & nd & nd & nd & nd & nd & nd \\
\hline
\end{tabular}


Table 2 Compounds identified by GC-MS analysis (Continued)

\begin{tabular}{|c|c|c|c|c|c|c|c|c|c|c|c|c|c|}
\hline & Carbohydrate compounds & & & & & & & & & & & & \\
\hline 17.168 & 1,6-Anhydro- $\beta$-D-glucose, trimethyl ether & nd & nd & nd & 1.35 & nd & nd & nd & 0.77 & nd & 0.83 & nd & nd \\
\hline 18 & $\begin{array}{l}\text { a-D-Galactopyranoside, methyl } \\
\text { 2,3,4,6-tetra-O-methyl }\end{array}$ & 1.74 & nd & nd & 3.17 & nd & nd & 0.73 & nd & nd & 4.24 & nd & nd \\
\hline 17.688 & 3,4,6-Tri-O-methyl-D-glucose & nd & nd & nd & nd & 0.54 & nd & nd & 0.83 & nd & nd & nd & nd \\
\hline 18.1280 & a-Methyl 4-methylmannoside & nd & nd & nd & nd & nd & nd & nd & 0.55 & nd & nd & nd & nd \\
\hline 21.355 & $\begin{array}{l}\text { 2,4,5,6,7-Pentamethoxyheptanoic acid, } \\
\text { methyl ester }\end{array}$ & nd & nd & nd & nd & 0.33 & nd & nd & nd & nd & nd & nd & nd \\
\hline 20.206 & $\beta$-D-Glucopyranose, 1,6-anhydro & nd & nd & nd & nd & nd & nd & nd & nd & 1.02 & nd & nd & nd \\
\hline 28.814 & 1,2,3,4-Tetramethylmannose & nd & nd & nd & nd & 1.85 & nd & nd & 1.75 & nd & nd & 0.58 & nd \\
\hline 28.631 & $\begin{array}{l}\text { a-D-Mannopyranoside, methyl } \\
\text { 2,3,4,6-tetra-O-methyl }\end{array}$ & nd & nd & 3.33 & nd & nd & nd & 0 & nd & nd & nd & nd & 0.53 \\
\hline \multirow[t]{2}{*}{37.425} & $\begin{array}{l}\text { a-D-Glucopyranoside, phenyl 2, } \\
\text { 3,4,6-tetra-O-methyl }\end{array}$ & nd & nd & nd & nd & 41.61 & 31.93 & nd & 22.57 & nd & nd & 5.62 & nd \\
\hline & Fatty acids as methyl ester & & & & & & & & & & & & \\
\hline 26.320 & Tridecanoic acid, 12-methyl-, methyl ester & 0.77 & nd & nd & 0 & nd & nd & 1.06 & 1.26 & nd & 0.80 & 1.62 & nd \\
\hline 26.323 & Methyl tetradecanoate & nd & nd & nd & 1.22 & nd & nd & nd & nd & nd & 0 & nd & nd \\
\hline 27.419 & 2-Hexadecenoic acid, methyl ester, (E) & nd & nd & nd & 0.32 & nd & nd & nd & nd & nd & 0.37 & nd & nd \\
\hline 27.901 & Tridecanoic acid, 12-methyl-, methyl ester & nd & nd & nd & 0.28 & nd & nd & nd & nd & nd & 0 & nd & nd \\
\hline 30.133 & Methyl hexadec-9-enoate & 1.06 & nd & nd & 2.94 & nd & nd & 0.84 & nd & nd & 0.47 & nd & nd \\
\hline 30.181 & 9-Octadecenoic acid (Z)-, methyl ester & 0 & nd & nd & 0 & nd & nd & nd & nd & nd & 0.13 & nd & nd \\
\hline 30.625 & Hexadecanoic acid, methyl ester & 4.22 & 2.26 & 0 & 7.28 & nd & nd & 4.05 & nd & 1.04 & 3.22 & 3.31 & 1.96 \\
\hline 30.327 & 6-Octadecenoic acid, methyl ester & nd & nd & nd & nd & nd & nd & nd & nd & nd & nd & 0.82 & nd \\
\hline 34.053 & 9-Octadecenoic acid, methyl ester, (E) & 1.27 & nd & nd & nd & nd & nd & nd & 0.73 & nd & nd & 0.84 & nd \\
\hline 34.164 & 8-Octadecenoic acid, methyl ester, (E) & 0.67 & nd & nd & nd & nd & nd & nd & nd & nd & nd & nd & nd \\
\hline 34.548 & Octadecanoic acid, methyl ester & 0.95 & 1.11 & 0 & 1.36 & 0.57 & nd & 2.15 & 1.61 & 0.28 & 1.40 & 1.60 & 0.67 \\
\hline \multirow[t]{2}{*}{38.161} & Eicosanoic acid, methyl ester & nd & nd & nd & 0.16 & nd & nd & nd & nd & nd & nd & nd & nd \\
\hline & Organic acids & & & & & & & & & & & & \\
\hline 26.507 & $\begin{array}{l}\text { Benzoic acid, 4,5-dimethoxy-2- } \\
\text { (4-methoxybenzenesulfonylamino)- }\end{array}$ & nd & nd & nd & nd & 1.31 & nd & nd & nd & nd & nd & nd & nd \\
\hline 40.052 & $\begin{array}{l}\text { Succinic acid, di(5-methoxy-3- } \\
\text { methylpent-2-yl) ester }\end{array}$ & nd & nd & nd & nd & nd & nd & nd & nd & nd & 0.36 & nd & nd \\
\hline \multirow[t]{2}{*}{43.743} & $\begin{array}{l}\text { Cyclopropanecarboxylic acid, } \\
\text { 2,2-dimethyl-3-(2-methyl-1-propenyl)-, } \\
\text { 2-methyl-4-oxo-3-(2-propenyl)-2- } \\
\text { cyclopenten-1-yl ester }\end{array}$ & nd & nd & nd & nd & nd & nd & nd & 0.70 & nd & nd & nd & nd \\
\hline & Aromatics and phenol derivatives & & & & & & & & & & & & \\
\hline 15.817 & 2-Methoxy-4-vinylphenol & nd & nd & nd & nd & nd & nd & nd & nd & 0.3 & 0 & nd & nd \\
\hline 19.337 & Phenol, 4,6-di(1,1-dimethylethyl)-2-methyl & nd & nd & nd & 0.24 & nd & nd & nd & nd & nd & 0.23 & nd & nd \\
\hline 24.653 & Isoelemicin & nd & nd & nd & nd & nd & nd & nd & nd & 0.49 & 0 & nd & nd \\
\hline 37.592 & Benzene, (1-methyldodecyl) & 0.31 & nd & nd & nd & nd & nd & 1.98 & nd & nd & 0.80 & nd & nd \\
\hline 41.779 & 1,2-Benzenedicarboxylic acid, diisooctyl ester & nd & nd & 69.71 & nd & nd & nd & 1.49 & nd & nd & 0.44 & nd & nd \\
\hline 41.784 & $\begin{array}{l}\text { 1,2-Benzenedicarboxylic acid, } \\
\text { mono(2-ethylhexyl) ester }\end{array}$ & 1.55 & nd & nd & nd & nd & 2.37 & nd & nd & nd & 0 & nd & 7.49 \\
\hline 21.512 & Phenol, 2,6-dimethoxy-4-(2-propenyl) & nd & nd & nd & nd & 0.25 & nd & nd & nd & nd & nd & nd & nd \\
\hline 35.007 & Phenol, 5-methoxy-2,3,4-trimethyl & nd & 0 & nd & nd & 0.22 & nd & nd & nd & nd & nd & nd & nd \\
\hline 37.803 & Benzene, (1-methylnonadecyl) & nd & 0.78 & nd & nd & nd & nd & nd & 1.15 & nd & nd & 1.36 & nd \\
\hline
\end{tabular}


Table 2 Compounds identified by GC-MS analysis (Continued)

\begin{tabular}{|c|c|c|c|c|c|c|c|c|c|c|c|c|c|}
\hline 22.015 & Benzoic acid, 4-hydroxy-3,5-dimethoxy & nd & nd & nd & nd & 0.21 & nd & nd & nd & nd & nd & nd & nd \\
\hline 22.016 & 1,2,3,4-Tetramethoxybenzene & nd & nd & nd & nd & nd & nd & nd & nd & nd & nd & 0.27 & nd \\
\hline 23.399 & Benzoic acid, 3,4-dimethoxy-, methyl ester & nd & nd & nd & nd & 0.72 & 1.41 & nd & nd & nd & nd & nd & 1.65 \\
\hline 25.152 & $\begin{array}{l}\text { 2-Propenoic acid, 3-(4-methoxyphenyl)-, } \\
\text { methyl ester }\end{array}$ & nd & nd & nd & 1.17 & 1.03 & nd & nd & 0.65 & nd & nd & 0.66 & nd \\
\hline 26.277 & $\begin{array}{l}\text { Benzenepropanoic acid, 3,4-dimethoxy-, } \\
\text { methyl ester }\end{array}$ & nd & nd & nd & nd & nd & 5.14 & nd & nd & nd & nd & nd & 3.27 \\
\hline 26.328 & Benzoic acid, 3,4,5-trimethoxy-, methyl ester & nd & nd & nd & 0 & nd & nd & nd & nd & 2.70 & nd & nd & nd \\
\hline 29.738 & $\begin{array}{l}\text { 2-Propenoic acid, 3-(3,4-dimethoxyphenyl)-, } \\
\text { methyl ester }\end{array}$ & 0.49 & nd & nd & 0 & 2.61 & 5.02 & nd & 0.75 & 4.24 & 0.23 & 1.24 & 3.21 \\
\hline \multirow[t]{2}{*}{36.154} & 2-Propenoic acid, 2-methyl-, dodecyl ester & 0 & nd & nd & 0 & nd & nd & nd & nd & nd & 0.12 & nd & nd \\
\hline & Terpenoids and steroids & & & & & & & & & & & & \\
\hline 43.074 & $17 \beta$-Hydroxy-6a-pentyl-4-oxa-5 $\beta$-androstan-3-one & nd & nd & nd & 0.74 & nd & nd & 0.93 & nd & nd & nd & nd & nd \\
\hline 43.412 & Dihydroxyisosteviol & 3.88 & nd & nd & 3.94 & nd & nd & 5.45 & 3.95 & nd & 3.69 & 0.73 & nd \\
\hline 42.582 & Dihydro-isosteviol methyl ester & nd & 2.04 & nd & nd & 0 & 9.42 & nd & nd & nd & nd & nd & 17.03 \\
\hline 43.332 & Methyl dihydroisosteviol & nd & nd & nd & nd & 1.47 & nd & nd & nd & nd & nd & nd & nd \\
\hline 43.665 & Isosteviol methyl ester & nd & 2.88 & nd & nd & 4.81 & nd & nd & 4.90 & 17.18 & nd & 4.68 & nd \\
\hline 39.849 & 5-Cholene, 3,24-dihydroxy- & nd & nd & nd & nd & nd & nd & nd & nd & nd & 0.12 & nd & nd \\
\hline 43.430 & Patchoulene & nd & nd & nd & 0.36 & nd & nd & nd & nd & nd & nd & nd & nd \\
\hline 45.538 & Androstan-17-one, 3-ethyl-3-hydroxy-, (5a) & nd & 0.78 & nd & nd & 2.89 & nd & nd & 1.03 & 0.50 & nd & 2.30 & nd \\
\hline 42.354 & $\begin{array}{l}\text { 5a,6a-Epoxy-17-oxo-6 } \beta \text {-pentyl-4-nor-3, } \\
\text { 5-secoandrostan-3-oicacid, methyl ester }\end{array}$ & nd & nd & nd & nd & nd & nd & nd & nd & nd & nd & nd & 0.31 \\
\hline 43.091 & 5 $\beta$-Pregnan-17a,21-diol-3,20-dione & nd & nd & nd & nd & nd & nd & nd & nd & nd & nd & nd & 25.88 \\
\hline \multirow[t]{2}{*}{43.434} & Pregnan-20-one, (5a,17a) & nd & nd & 2.48 & nd & nd & nd & nd & nd & nd & nd & nd & nd \\
\hline & Alcohols & & & & & & & & & & & & \\
\hline 3.974 & Ethanol, 2-(2-methoxyethoxy) & nd & nd & nd & nd & nd & nd & nd & nd & 1.18 & 0.33 & nd & nd \\
\hline 6.715 & 1-Hexanol, 2-ethyl & 1.65 & & 7.48 & 2.71 & 0.39 & 1.13 & 0.86 & nd & nd & 3.39 & nd & 1.19 \\
\hline 12.925 & Ethanol, 2-phenoxy & nd & nd & nd & nd & nd & nd & nd & nd & 0.63 & nd & nd & nd \\
\hline \multirow[t]{2}{*}{42.010} & 9-t-Butyltricyclo[4.2.1.1 (2,5)]decane-9,10-diol & nd & nd & nd & nd & nd & nd & nd & nd & nd & nd & 1.03 & nd \\
\hline & Jnidentified & & & & & & & & & & & & \\
\hline 30.542 & & nd & nd & nd & nd & nd & nd & nd & nd & nd & nd & nd & 3.14 \\
\hline 31.625 & & nd & nd & nd & nd & nd & nd & nd & nd & nd & nd & nd & 0.74 \\
\hline 31.825 & & nd & nd & nd & nd & nd & nd & nd & nd & nd & nd & nd & nd \\
\hline 32.184 & & nd & nd & nd & nd & 0.79 & nd & nd & nd & nd & nd & nd & nd \\
\hline 35.248 & & nd & nd & nd & nd & 0.77 & nd & nd & nd & nd & nd & nd & nd \\
\hline 38.362 & & nd & nd & nd & nd & nd & nd & nd & nd & nd & 0.42 & nd & nd \\
\hline 39.253 & & nd & nd & nd & nd & nd & nd & nd & nd & nd & 0.09 & nd & nd \\
\hline 40.033 & & nd & nd & nd & nd & nd & nd & nd & nd & nd & nd & 0.43 & nd \\
\hline 40.230 & & nd & nd & nd & 0.20 & nd & nd & nd & nd & nd & 0.37 & nd & nd \\
\hline 40.833 & & nd & nd & nd & nd & nd & nd & nd & nd & nd & nd & nd & 0.18 \\
\hline 40.964 & & nd & nd & nd & nd & nd & nd & nd & nd & nd & 0.31 & nd & nd \\
\hline 41.908 & & nd & nd & nd & 0.49 & nd & nd & nd & nd & nd & 0.41 & nd & nd \\
\hline 42.157 & & nd & nd & nd & nd & nd & nd & nd & nd & nd & nd & 0.24 & nd \\
\hline 43.746 & & nd & nd & nd & nd & nd & nd & nd & 0.43 & nd & 0 & nd & nd \\
\hline 44.305 & & nd & nd & nd & nd & nd & nd & nd & nd & nd & 0.27 & nd & nd \\
\hline
\end{tabular}




\section{Table 2 Compounds identified by GC-MS analysis (Continued)}

\begin{tabular}{|c|c|c|c|c|c|c|c|c|c|c|c|c|}
\hline 44.532 & nd & nd & nd & 0 & nd & nd & nd & nd & nd & nd & nd & 0.45 \\
\hline 45.275 & nd & nd & nd & 0.74 & nd & nd & 0.35 & nd & nd & 0.89 & nd & nd \\
\hline 46.026 & nd & nd & nd & nd & nd & nd & 0 & nd & nd & 0.11 & nd & nd \\
\hline 46.277 & nd & nd & nd & nd & nd & nd & 0 & nd & nd & nd & nd & 1.72 \\
\hline 46.606 & nd & nd & nd & nd & nd & 0.53 & 0 & nd & nd & 0 & nd & nd \\
\hline
\end{tabular}

Compound exudates from maize seedlings at different growth stages (7, 14, and 21 days) induced or not (control) by humic acids (HA), Herbaspirillum seropedicae ( $H$. seropedicae), and HA and $H$. seropedicae. nd, not detected.

found in the exudates, though in only small quantities in the control.

Compounds identified on day 21 are shown in Table 2. Exudates collected on that day contained a smaller diversity of compounds than earlier collections. Hexanol was found in control exudates and ethanol phenoxy products in treatment PGPB, likely due to carbohydrate hydrolysis reactions. Nitrogenous compounds were the main exudate products retained by the RP C18 column; carbonic acid, monoamide, $N$-(2,4-dimethoxyphenyl)-, and butyl ester were found only in control exudates on day 21. 2,5-Dimethoxyphenyl isocyanate occurred in elevated quantities in exudates of treatments HA, PGPB, and $\mathrm{HA}+\mathrm{PGPB}$; a derivative from acetamide and dimethoxy amino toluene was also abundant. A nitrogenous compound identified as 4-(diethylamino)salicylaldehyde was found in treatment PGPB exudates on day 21, but not on days 7 and 14. Finally, products from acetamide were typical of exudates in treatments PGPB and HA + PGPB; they were found on day 21 at 29.34 and $32.13 \mathrm{~min}$.

\section{Discussion}

Our aim in the present work was to determine the effects of single and combined applications of humic acid and the endophytic diazotrophic bacterium $H$. seropedicae on exudation profiles of maize roots. This was a first step in identifying compounds that may be involved in rhizosphere interactions and modulation of root colonization and endophytic establishment of bacteria.

We demonstrated enhanced root colonization by $H$. seropedicae in the presence of humic acids (Figure 1). Previous work showed that the elevated bacterial population associated with maize roots may be explainable in part by humic acid sorption at the plant cell wall surface, which is associated with increased attachment and endophytic colonization by $H$. seropedicae $[9,10]$. Moreover, the main infection sites for $H$. seropedicae in grasses are the points of lateral root emergence, which are induced by humic acid and may contribute to enhanced establishment of the endophytic population [11].

Canellas et al. [12] and Puglisi et al. [13] previously observed changes in exudation profiles of organic acids in maize seedlings treated with humic acid. However, identifying causal relationships in changed exudate profiles is complex, and results may not always be directly attributable to treatment effects on the quantities and the composition of root exudates. Juo and Storzky [36] observed decreases in protein and carbohydrate release with increasing plant age using an electrophoretic approach. They suggested that the RP C18 column used to retain the exudates may have limited their quantitative analysis. We noticed on day 21 (across all treatments) that exudate yields had declined (Figure 2) relative to earlier collections on days 7 and 14.

${ }^{1} \mathrm{H}$ NMR spectroscopy (Figures 3,4,5) demonstrated differences in exudate profiles under the influence of the treatments, and PCA analysis revealed significant changes from day 14 onward (Figure 6). Roncatto-Maccari et al. [37] observed that 3 days after maize inoculation, the population of $H$. seropedicae mainly comprises single cells attached to the root surface. They (loc. cit.) found that after 12 days the cells were connected and forming aggregates; they detected (by scanning electron microscopy) a halo of mucilage surrounding the bacterial colony on the roots of inoculated maize. Although plant-bacterial signaling is considered a rapid phenomenon, changes in exudate NMR spectra in our experiment occurred only after extensive colonization on the root axis (i.e., on day 14).

One group of candidate biomolecules emerging from this prospective study comprised a number of compounds that have been identified as possible inducing agents of the quorum sensing (QS) system, which is a mechanism responsible for modulating population density, biofilm formation, and the specific genetic machinery for niche persistence and colonization at the root level. These compounds include oligopeptides and substituted gamma-butyrolactones, 3-hydroxypalmitic acid methyl ester, 3,4-dihydroxy-2-heptylquinoline, and a furanosyl borate diester ([5] and references therein). Interestingly, our analyses of the overall transcriptome profile of $H$. seropedicae strain Smr1 (as part of a broad examination of gene expression in planktonic and biofilm lifestyles) have shown that biofilm maturation is coupled with differentially regulated genes involved in aromatic metabolism and multidrug transport efflux activation (data not shown). These potential quorum sensing inducers may be key molecules in the well-known rhizosphere competence of $H$. seropedicae [14,25]. Functional studies linking 
these compounds to chemotaxis and biofilm induction are urgently required.

Another interesting future study that may develop from our prospective explorations might be an evaluation of the ability of $H$. seropedicae to use secondary metabolites as carbon sources that are exclusively or primarily exuded from maize roots treated with this bacterium. The presence of a catabolic machinery for specific cleavage of these compounds (especially compounds with antimicrobial properties) would represent a nutritional advantage for the colonization of the host plant rhizosphere.

We identified hexadecanoic acid (palmitic acid) in exudates of all treatments on days 7 and 14, but by day 21 , these compounds were detected only in treatment PGPB. Non-quinoline derivatives of other heterocyclic aromatic $\mathrm{N}$ compounds belonging to the pyrimidine class were collected exclusively in treatments PGPB and HA + PGPB (Table 2). The most remarkable difference in root exudates among treatments was in $\mathrm{N}$ compounds; these increased with time in all treatments other than the controls, in which quantities decreased. Some nitrogenous compounds, like benzenamine $\left(\mathrm{C}_{6} \mathrm{H}_{5} \mathrm{CONH}_{2}\right)$, 2,4-dimethoxy, 3,4-dimethoxy-6-amino toluene, and 2,5dimethoxyphenyl isocyanate, were found in the exudates; they are probably derivatives of aromatic/phenolic compounds that react with TMAH used in methoxylation since the phenolic compounds, which are the main secondary metabolites synthesized by maize, react promptly with $\mathrm{NH}_{2}$. Pyrimidinediones comprise a class of chemical compounds characterized by a pyrimidine ring substituted with two carbonyl groups. 2,4(1H,3H)-pyrimidinedione, 1,3,5-trimethyl is typical of uracil derivatives, i.e., nucleobases in the nucleic acid of RNA. Pyrrole carboxylic acid derivatives, which may originate from the L-tryptophan pathway, have been described as antibacterial agents. Finally, we found one polyamine derivative of spermine. Such derivatives have been implicated in a wide range of metabolic processes in plants, ranging from cell division and organogenesis to protection against stress; they act as plant and microbial growth stimulants and chemoattractants [5].

Stearic and palmitic acids were the main fatty acids exuded by maize seedling roots. These fatty acids are predominant in most plants; they are synthesized by acetylCoA carboxylase and fatty acid synthase. Quantities of these fatty acids exuded by the controls differed between days 14 and 21. Stearic and palmitic acids were exuded by maize seedlings treated with $H$. seropedicae with or without HA (Tables 2). Terpenoids derived from the kaurenoic acid pathway, including gibberellic acids, were found in all treatments. However, their diversity was highest in treatments PGPB and HA + PGPB. A significant increase in transcript levels of ent-kaurene oxidase genes that are involved in gibberellin synthesis occurs in maize seedlings treated with $H$. seropedicae [38]. The agreement between gene expression in the gibberellin biosynthesis pathway (Zmko1) and the exudation profile in the same biological model supports our suggestion that the gibberellin synthesis pathway in root tissues is modulated by $H$. seropedicae colonization.

Root colonization by $H$. seropedicae in graminaceous plants requires movement of the bacteria to the root surface followed in sequence by adsorption and attachment to the cell wall surface $[25,27]$. Attached bacteria may persist at the root surface as aggregates or biofilms, and they occasionally trigger plant responses that induce lateral root sites, which serve as entryways for endophytic establishment in the plant host. Humic acids are heterogeneous, irregular, and amphiphilic structures with high charge densities and hydrophobic cores that facilitate adsorption phenomena and lateral root induction [39]. As H. seropedicae is a flagellated cell, there is a potential for induction of flagellar activity by plant-released compounds (chemotactic substances), as previously described for other bacteria [40].

From the inventory of exuded compounds, it may be possible to select candidate molecules as quorum sensing mediators of biofilm maturation, as substrates for catabolic mechanisms to supply energy, or as detoxifiers, thereby increasing the rhizosphere competence of Herbaspirillum. Furthermore, changes in rhizosphere hydrophobicity by fatty acid exudates may be an important mechanism for preserving cell viability. We detected relatively large amounts of gibberellic acid precursor in exudates isolated from maize seedlings treated with $H$. seropedicae; this bacterium induced changes in nitrogenous compounds as well.

\section{Conclusion}

The number of unidentified compounds was much higher in treatments PGPB and HA + PGPB than in the control. The limitations of a conventional GC-MS approach, such as low mass resolution and the need for previous volatilization of compounds, suggest that the instrument should be combined with other analytical tools, like liquid chromatography coupled to high mass definition spectroscopy. We found that root exudates from maize seedlings mostly comprised fatty acids and nitrogenated compounds. We observed changes in root exudate profiles in maize seedlings treated with HA and $H$. seropedicae. These changes were most pronounced on days 14 and 21 , when there was enhanced fatty acid exudation in treatment $\mathrm{HA}$ and elevated nitrogenate and terpene exudation from treatment PGPB.

This is the first study to date that has evaluated the combined application of a plant growth-promoting bacteria and humic acid on maize root exudation profiles. This study was carried out on controlled conditions in a hydroponic culture. Overall, the chemical changes we 
observed in the rhizosphere may improve the survival, persistence, and biological activity of $H$. seropedicae in the presence of humic substances and provide a pool of candidate molecules for use as additives in inoculant technology formulation, which will contribute substantially to progress in arable agriculture. However, the findings of this hydroponic study need to be confirmed under real soil conditions.

\section{Additional files}

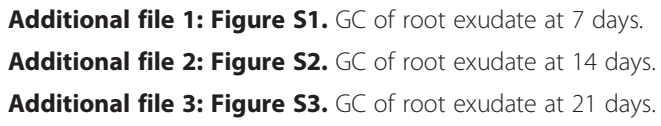

\section{Competing interests}

The authors declare that they have no competing interests.

\section{Authors' contributions}

LSL conducted the laboratory experiments and did the first inventory of exudates. FLO and LPC wrote and discussed the manuscript. RRO performed and interpreted the NMR data. MRGV reviewed the nomenclature of compounds and the biosynthesis route. NOA was responsible for the multivariate analysis. All authors read and approved the final manuscript.

\section{Acknowledgements}

The work was supported by Conselho Nacional de Desenvolvimento Científico e Tecnológico (CNPq), Fundação de Amparo à Pesquisa do Estado do Rio de Janeiro (FAPERJ), Instituto Nacional de Ciência e Tecnologia (INCT) para a Fixação Biológica de Nitrogênio, Internacional Foundation of Science (IFS), and OCWP.

\section{Author details}

${ }^{1}$ Núcleo de Desenvolvimento de Insumos Biológicos para a Agricultura (NUDIBA), Universidade Estadual do Norte Fluminense Darcy Ribeiro (UENF), Av. Alberto Lamego, 2000, Campos dos Goytacazes, 28013-602 Rio de Janeiro, Brazil. ' Laboratório de Ciências Químicas (LCQUI), Universidade Estadual do Norte Fluminense Darcy Ribeiro (UENF), Av. Alberto Lamego, 2000, Campos dos Goytacazes, 28013-602 Rio de Janeiro, Brazil.

Received: 12 June 2014 Accepted: 30 October 2014

Published online: 27 November 2014

\section{References}

1. Vivanco JM, Baluška F (2012) Secretions and exudates in biological systems: 12. Signaling and communication in plants. Springer, Berlin, p 290

2. Jones DL, Nguyen C, Finlay RD (2009) Carbon flow in the rhizosphere: carbon trading at the soil-root interface. Plant Soil 321:5-33

3. Uren NC (2007) Types, amounts, and possible functions of compounds released into the rhizosphere by soil-grown plants. In: Pinton R, Varanini Z, Nannipieri P (ed) The rhizosphere: biochemistry and organic substances at the soil-plant interface. CRC Press, Boca Raton, pp 1-21

4. Mimmo T, Hann S, Jaitz L, Cescoa S, Gessa CE, Puschenreiter M (2011) Time and substrate dependent exudation of carboxylates by Lupinus albus L. and Brassica napus L. Plant Physiol Biochem 49:1272-1278

5. Faure D, Vereecke D, Leveau JHJ (2009) Molecular communication in the rhizosphere. Plant Soil 321:279-303

6. Azaizeh HA, Marschner H, Römheld V, Wittenmayer L (1995) Effects of vesicular abruscular micorrhizal fungus and other soil microorganisms on growth, mineral nutrient acquisition and root exudation of soil-grown maize plants. Mycorrhiza 5:321-327

7. Neumann G, Römheld V (2007) The release of root exudates as affected by the plant physiological status. In: Pinton R, Varanini Z, Nannipieri P (ed) The rhizosphere: biochemistry and organic substances at the soil-plant interface. CRC Press, Boca Raton, pp 24-72
8. Hassan S, Mathesius U (2012) The role of flavonoids in root-rhizosphere signalling: opportunities and challenges for improving plant-microbe interactions. J Exp Bot 63:3429-3444

9. Canellas LP, Martínez-Balmori D, Médici LO, Aguiar NO, Campostrini E, Rosa RC, Façanha A, Olivares FL (2013) A combination of humic substances and Herbaspirillum seropedicae inoculation enhances the growth of maize (Zea mays L.). Plant Soil 366:119-132

10. Canellas LP, Olivares FL (2014) Physiological responses to humic substances as plant growth promoter. Chem Biol Technol Agr 1:3

11. Canellas LP, Olivares FL, Okorokova-Façanha AL, Façanha AR (2002) Humic acids isolated from earthworm compost enhance root elongation, lateral root emergence, and plasma membrane $\mathrm{H}^{+}$-ATPase activity in maize roots. Plant Physiol 130:1951-1957

12. Canellas LP, Teixeira Junior LRL, Dobbss LB, Silva CA, Medici LO, Zandonadi DB, Façanha AR (2008) Humic acids cross interactions with root and organic acids. Ann Appl Biol 153:157-166

13. Puglisi E, Pascazio S, Suciu N, Cattani I, Fait G, Spaccini R, Crecchio C, Piccolo A, Trevisan M (2013) Rhizosphere microbial diversity as influenced by humic substance amendments and chemical composition of rhizodeposits. J Geochem Expl 129:82-94

14. Olivares FL, Baldani VLD, Reis VM, Baldani Jl, Döbereiner J (1996) Occurrence of the endophytic diazotrophs Herbaspirillum spp. in roots, stems and leaves predominantly of Gramineae. Biol Fertil Soils 21:197-200

15. Roesch LFW, Camargo FAO, Bento FM, Triplett EW (2007) Biodiversity of diazotrophic bacteria within the soil, root and stem of field-grown maize. Plant Soil 302:91-104

16. Pan B, Bai YM, Leibovitch S, Smith DL (1999) Plant-growth-promoting rhizobacteria and kinetin as ways to promote corn growth and yield in a short-growing-season area. Eur J Agr 11:179-186

17. Riggs PJ, Chelius MK, Iniguez AL, Kaeppler SM, Triplett EW (2001) Enhanced maize productivity by inoculation with diazotrophic bacteria. Austr J Plant Physiol 28:829-836

18. Oliveira ALM, Urquiaga S, Döbereiner J, Baldani J (2002) The effect of inoculating endophytic N2-fixing bacteria on micropropagated sugarcane plants. Plant Soil 242:205-215

19. Lucy ME, Reed E, Glick BR (2004) Applications of free-living plant growthpromoting rhizobacteria. A van Leeuw J Microb 86:1-25

20. Kennedy IR, Choudhury ATMA, Kecskés ML (2004) Non-symbiotic bacterial diazotrophs in crop-farming systems: can their potential for plant growth promotion be better exploited? Soil Biol Biochem 36:1229-1244

21. Shaharoona B, Arshad M, Zahir ZA, Khalid A (2006) Performance of Pseudomonas spp. containing ACC-deaminase for improving growth and yield of maize (Zea mays L.) in the presence of nitrogenous fertilizer. Soil Biol Biochem 38:2971-2975

22. Mehnaz S, Kowalik T, Reynolds B, Lazarovits G (2010) Growth promoting effects of corn (Zea mays) bacterial isolates under greenhouse and field conditions. Soil Biol Biochem 42:1848-1856

23. Montañez A, Sicardi M (2013) Effects of inoculation on growth promotion and biological nitrogen fixation in maize (Zea mays L.) under greenhouse and field conditions. Bas Res J Agric Sci Rev 2:102-110

24. Pedrosa FO, Monteiro RA, Wassem R, Cruz LO, Ayub RA, Colauto NB, Fernandez M, Fungaro MHP, Grisard E, Hungria M, Madeira HM, Humberto MF, Nodari RO, Osaku CA, Petzl-Erler ML, Terenzi H, Vieira LGE, Steffens MBR, Weiss VA, Pereira LFP, Almeida MIM, Alves LR, Marin A, Araujo LM, Balsanelli E, Baura VA, Chubatsu LS, Faoro H, Favetti A, Friedermann G, et al. (2011) Genome of Herbaspirillum seropedicae strain SmR1, a specialized diazotrophic endophyte of tropical grasses. PLoS Genet 7(5):e1002064

25. James EK, Olivares FL (1998) Infection and colonization of sugarcane and other graminaceous plants by endophytic diazotrophs. Crit Rev PI Sci 17:77-119

26. Baldotto LEB, Olivares FL (2008) Phylloepiphytic interaction between bacteria and different plant species in a tropical agricultural system. Can J Microb 54:918-931

27. Monteiro RA, Balsanelli E, Wassem R, Anelis M, Brusamarello-Santos LCC, Schmidt MA, Tadra-Sfeir MZ, Pankievicz VCS, Cruz LM, Chubatsu LS, Pedrosa FO, Souza EM (2012) Herbaspirillum-plant interactions: microscopical, histological and molecular aspects. Plant Soil 356:175-196

28. Hungria M (1994) Sinais Moleculares envolvidos na nodulação das leguminosas por rizóbio. Rev Bras Ci Solo 18:339-364

29. Gough C, Galera C, Vasse J, Webster G, Cocking EC, Dénarié J (1997) Specific flavonoids promote intercellular root colonization of Arabidopsis thaliana by Azorhizobium caulinodans ORS571 (1997). Mol Plant-Micr Interac 10:560-570 
30. Tadra-Sfeir MZ, Souza EM, Faoro H, Múller-Santos M, Baura VA, Tuleski TR, Rigo LU, Yates MG, Wassem R, Pedrosa FO, Monteiro RA (2011) Naringenin regulates expression of genes involved in cell wall synthesis in Herbaspirillum seropedicae. Appl Environ Microbiol 77:2180-2183

31. Marin AM, Souza EM, Pedrosa FO, Souza LM, Sassaki GL, Baura VA, Yates MG, Wassem R, Monteiro RA (2012) Naringenin degradation by the endophytic diazotroph Herbaspirillum seropedicae SmR1. Microbiol 159:167-75

32. Balsanelli E, Tuleski TR, de Baura VA, Yates MG, Chubatsu LS, Pedrosa FO, de Souza EM, Monteiro RA (2013) Maize root lectins mediate the interaction with Herbaspirillum seropedicae via N-acetyl glucosamine residues of lipopolysaccharides. PLoS One 8(10):e77001. doi:10.1371/journal.pone.0077001

33. Marks BB, Nogueira MA, Hungria M, Megias M (2013) Biotechnological potential of rhizobial metabolites to enhance the performance of Bradyrhizobium spp. and Azospirillum brasilense inoculants with soybean and maize. AMB Express 3:2

34. Baldani Jl, Pot B, Kirchhof G, Falsen E, Baldani VLD, Olivares FL, Hoste B, Kersters K, Hartmann A, Gillis M, Döbereiner J (1996) Emended description of Herbaspirillum, inclusion of [Pseudomonas] rubrisubalbicans, a mild plant pathogen, as Herbaspirillum rubrisubalbicans comb. Nov., and classification of a group of clinical isolates (EF group 1) as Herbaspirilum species 3. Int J Syst Bact 46:802-810

35. Döbereiner J, Baldani VLD, Baldani Jl (1995) Como isolar e identificar bactérias diazotróficas de plantas não leguminosas. Embrapa Agrobiologia, Seropédica

36. Juo P-S, Storkzky G (1970) Electrophoretic separation of proteins from roots and root exudates. Can J Bot 48:713-718

37. Roncato-Maccari LDB, Ramos HJO, Pedrosa FO, Alquini Y, Chubatsu LS, Yates MG, Rigo LU, Stefens MBR, Souza EM (2003) Endophytic Herbaspirillum seropedicae expresses nif genes in gramineous plants. FEMS Microbiol Ecol 45:39-47

38. Amaral FP, Bueno JCF, Hermes VS, Arisi ACM (2014) Gene expression analysis of maize seedlings (DKB240 variety) inoculated with plant growth promoting bacterium Herbaspirillum seropedicae. Symbiosis doi:10.1007/ s13199-014-0270-6

39. Piccolo A (2002) The supramolecular structure of humic substances. A novel understanding of humus chemistry and implications in soil science. Adv Agr 75:57-134

40. Ashy AM, Watson MD, Shaw CH (1987) A Ti-plasmid determined function is responsible for chemotaxis of Agrobacterium tumefaciens towards the plant wound acetosyringone. FEMS Microbial Lett 41:189-198

doi:10.1186/s40538-014-0023-z

Cite this article as: da Silva Lima et al.: Root exudate profiling of maize seedlings inoculated with Herbaspirillum seropedicae and humic acids. Chemical and Biological Technologies in Agriculture 2014 1:23.

\section{Submit your manuscript to a SpringerOpen ${ }^{\odot}$ journal and benefit from:}

- Convenient online submission

- Rigorous peer review

- Immediate publication on acceptance

- Open access: articles freely available online

- High visibility within the field

- Retaining the copyright to your article

Submit your next manuscript at $>$ springeropen.com 